\title{
The Oligocene nannolith Sphenolithus evolutionary lineage: morphometrical insights from the palaeo-equatorial Pacific Ocean
}

\author{
TEODORA BLAJ ${ }^{1,2, *}$, JORIJNTJE HENDERIKS ${ }^{1,3}$, JEREMY R. YOUNG $^{4} \&$ EMIL REHNBERG $^{5}$ \\ ${ }^{1}$ Department of Geology and Geochemistry, Stockholm University SE-106 91 Stockholm, Sweden \\ ${ }^{2}$ Current address: PetroStrat Limited Tan-y-Graig, Parc Caer Seion, Conwy LL32 8FA, Wales, UK \\ ${ }^{3}$ Current address: Department of Earth Sciences, Paleobiology Program, Uppsala University SE-75 236 Uppsala, Sweden \\ ${ }^{4}$ Palaeontology Department, The Natural History Museum London SW7 5BD, UK \\ ${ }^{5}$ Department of Mathematical Statistics, Stockholm University SE-106 91 Stockholm, Sweden \\ ${ }^{*}$ Corresponding author (e-mail: teodora.blaj@petrostrat.com)
}

\begin{abstract}
Changes in morphology within the biostratigraphically important Oligocene nannofossil lineage, Sphenolithus predistentus, $S$. distentus and S. ciperoensis were investigated in carbonate sediments from the palaeo-equatorial Pacific Ocean Site 1218 in order to determine the nature of this evolutionary lineage. Using differences in their morphology and stratigraphical ranges, the aim of this study was to determine whether these taxa represent an anagenetic evolutionary lineage or a set of discrete species with overlapping stratigraphical ranges. A total of 1215 specimens from 12 samples were analysed morphometrically and the basal ratio, i.e. the ratio between the basal width and proximal cycle height, was identified as a key parameter for the study of this lineage. We conclude that $S$. distentus and $S$. predistentus are intergradational species forming an anagenetic lineage but that $S$. ciperoensis is a discrete species which evolved relatively abruptly in the Late Oligocene. J. Micropalaeontol. 29(1): 17-35, May 2010.
\end{abstract}

KEYWORDS: Sphenolithus, evolutionary lineage, Oligocene, morphometry, ODP Leg 199 Site 1218

\section{INTRODUCTION}

A continuous Oligocene carbonate section was recovered at Ocean Drilling Program (ODP) Site 1218 ( $8^{\circ} 53.38^{\prime} \mathrm{N} ; 135^{\circ}$ $22.00^{\prime} \mathrm{W}$; water depth $4826 \mathrm{~m}$ ) from the palaeo-equatorial Pacific Ocean (Lyle et al., 2002; Wilson et al., 2006). A wellconstrained magnetostratigraphy and a high-resolution astronomically calibrated cyclostratigraphy have been established and integrated to provide an excellent age model for this Oligocene section (Lanci et al., 2005; Pälike et al., 2006). This age model was used for calibration of calcareous nannofossil bioevents (Blaj et al., 2009). During this study problems emerged in the identification of sphenolith species used as biostratigraphical markers and so a morphometrical study was undertaken to resolve these issues. The main difficulty to investigate was to clearly distinguish between the transitional forms and the end-member morphotypes of the lineage.

The diversity of Oligocene calcareous nannofossil assemblages is relatively low (Bown et al., 2004) (Fig. 1a), and the zonal marker events in the classical biostratigraphical zonations of Martini (1971) and Bukry (1978) are wider spaced than in other Cenozoic series (Fig. 1b). Hence, it is particularly important that Oligocene nannofossil events are clearly defined and well calibrated.

The genus Sphenolithus is particularly important for the subdivision of Oligocene time (Roth et al., 1970). Index species belong to $S$. predistentus-distentus-ciperoensis and transitional forms between these taxa (Huang, 1977; Olafsson \& Villa, 1992). This group is well represented in the assemblage through the Late Oligocene of Site 1218 and thus is suitable for study of evolutionary changes and phenotypic variations of this lineage.

The main aim of this study is to clarify taxonomic concepts of these biostratigraphically important Oligocene sphenoliths by studying their evolutionary patterns in order to understand how phenotypic variations could be used for identifying endmembers within this lineage. Previous authors (e.g. Bramlette \&
Wilcoxon, 1967; Roth et al., 1970; Haq, 1971) have agreed that three successive species can be distinguished, $S$. predistentus, $S$. distentus and $S$. ciperoensis, and that they are directly related. However, there is no consensus whether this sphenolith lineage is a set of discrete species resulting from a sequence of cladogenetic events or whether it represents an anagenetic sequence of intergradational morphotypes (Fig. 2a).

An evolutionary lineage is a sequence of species that form a line of descent, in which each new species is the direct result of speciation from an immediate ancestral species. In this context, an intergrading (anagenetic) lineage refers to a series of species that grade into each other and have some overlap in their stratigraphical ranges (Fig. 2a (I)), i.e. at any one time only one biospecies is present but the continuous morphological change allows a set of chronospecies to be arbitrarily defined, each of which has a discrete stratigraphical range. The alternative possibility is that morphological variation has arisen as a result of a sequence of cladogenetic events and so there is a series of separate species that have distinct morphologies, no transitional forms and distinct stratigraphic ranges (Fig. 2a (II)).

\section{MATERIAL AND METHODS}

Morphometric measurements of $S$. predistensus, $S$. distentus and $S$. ciperoensis specimens were carried out on a total of 12 samples (Table 1) containing abundant and well-preserved sphenoliths from different Oligocene stratigraphical intervals between 29.86 and 26.76 Ma at Site 1218 (Fig. 3; ten samples). This time interval was chosen as the morphologically similar sphenoliths, identified as $S$. predistensus and $S$. distentus, co-occurred within this interval and because of the presence of $S$. ciperoensis in the upper part of the investigated interval. Two additional samples were selected below this interval to investigate the characteristics of 'transitional' forms within $S$. predistentus-dominated assemblages at 31.60 and $33.02 \mathrm{Ma}$, 


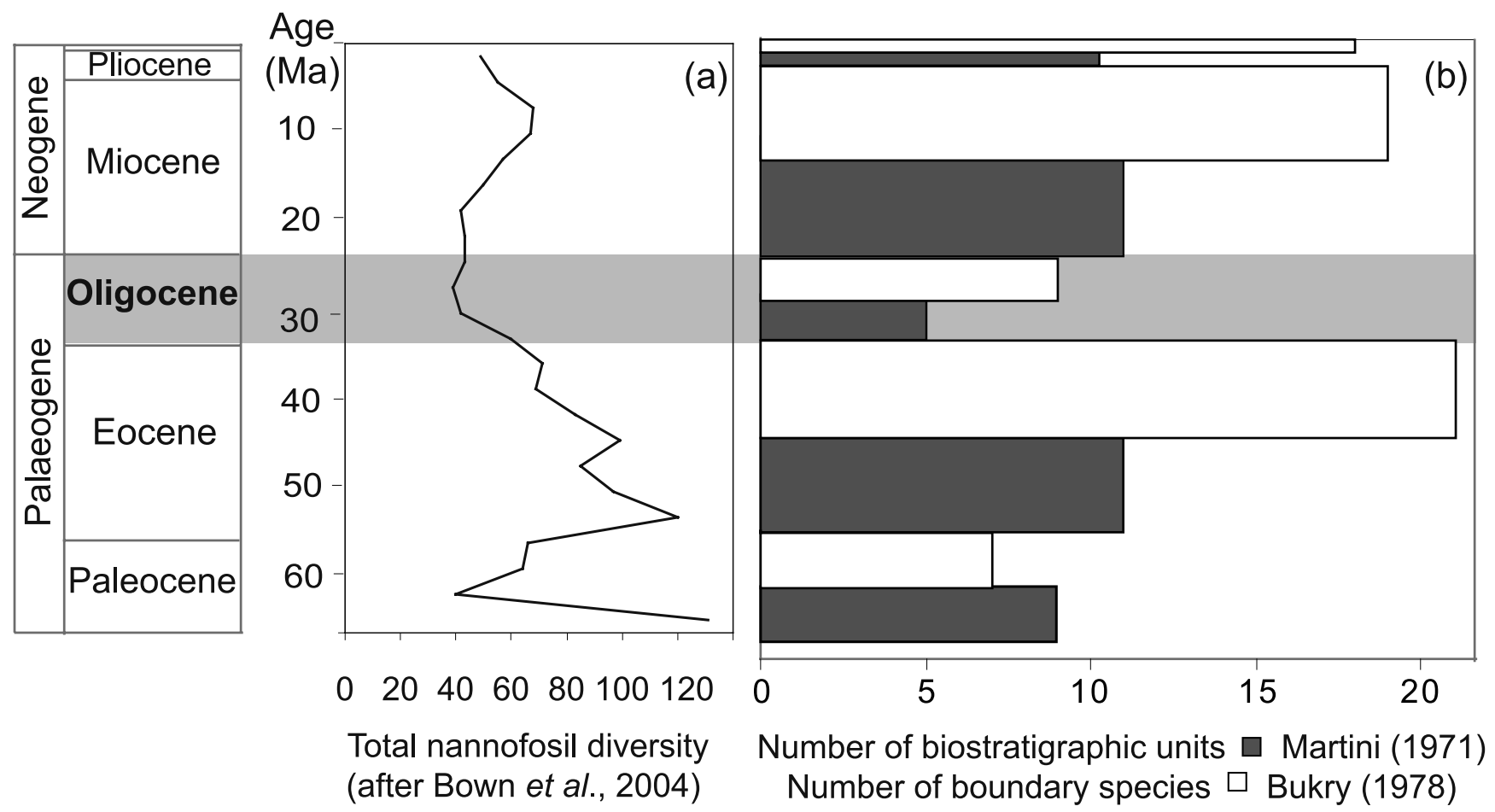

Fig. 1. Cenozoic nannofossil diversity data: (a) total nannofossil diversity (after Bown et al., 2004); (b) the number of biostratigraphical units (Martini, 1971) and boundary species (Bukry, 1978) used in the standard Cenozoic zonation schemes. Note the low diversity and low number of biostratigraphic events/boundary species in the Oligocene (shaded interval).

which will be discussed separately (Fig. 3; see also Blaj et al., 2009). Thus, our study focused on the problematic interval during which a range of morphotypes co-occur, as opposed to the earlier interval during which $S$. predistentus predominates or the subsequent interval when only $S$. ciperoensis occurs.

All nannofossil analyses were performed on smear-slides prepared from raw sediment samples using standard techniques (Haq \& Lohmann, 1976; Perch-Nielsen, 1985). Light microscope (LM) images were captured using a Zeiss Axioplan microscope equipped with a Leica DFC 280 digital camera, at $1600 \times$ magnification. The images were taken of sphenolith specimens viewed at $45^{\circ}$ to the polarizers; in this orientation the extinction line between the apical cycle and proximal cycle is clearly distinguishable. One hundred randomly selected specimens were imaged from each of the ten samples of the S. predistensusdistentus-ciperoensis group (Appendix A) and measured. We have chosen to focus on measurements of the proximal cycle height and basal width (Fig. 2b), because the optical behaviour of the proximal elements cycle in polarized light provides the main criterion by which the $S$. predistensus-distentus-ciperoensis lineage is taxonomically separated (Roth et al., 1970), and also because the apical spine was often broken and/or missing.

Measurements of sphenolith proximal cycle height and basal width were made on calibrated digital images (1 pixel corresponds to $0.054 \mu \mathrm{m}$ ) using the public domain program ImageJ (http://rsb.info.nih.gov/ij/). In order to increase the accuracy of the measurements, the statistical mean (Appendix A) of two measurements was used. Selected sphenolith samples were also studied by scanning electron microscopy using a Phillips XL30 Field Emission Scanning Electron Microscope (SEM) at the
Natural History Museum, London in order to investigate in more detail their morphological features.

\section{TAXONOMIC REMARKS}

Oligocene sphenolith evolutionary lineage

Sphenolithus is an extinct genus of nannoliths, having a long stratigraphical range (Paleocene-Pliocene) and commonly used in Cenozoic biostratigraphy and especially for the subdivision of the Oligocene (Bramlette \& Wilcoxon, 1967; Roth et al., 1970; Haq, 1971; Martini, 1971; Bukry, 1975; Okada \& Bukry, 1980). The sphenoliths are conical nannofossils with a concave base, formed from cycles of elements radiating from a common centre. The species of the studied Sphenolithus lineage, i.e. $S$. predistentus, $S$. distentus and $S$. ciperoensis, have a distinctive structure with an apical cone formed of two sub-parallel elements separated by a median suture and a single proximal cycle of radiating elements. In well-preserved specimens a long spine often extends from the tip of each apical cone element (e.g. Plate 1B, figs 21, 26). The apical cycle formed of two elements, the pair of apical spines, and the presence of only a single cycle of basal elements distinguish this set of species from other sphenoliths. Variation within these Sphenolithus species lead to them being one of the first calcareous nannofossil genera in which an evolutionary lineage was documented (Bramlette \& Wilcoxon, 1967). The S. predistentus, S. distentus and S. ciperoensis lineage evolved through the late Eocene and Oligocene. Most observations of this lineage are based on qualitative separation of the morphotypes, using their appearance in cross-polarized light. In this study, the criteria used to separate these morphologically 
(a)

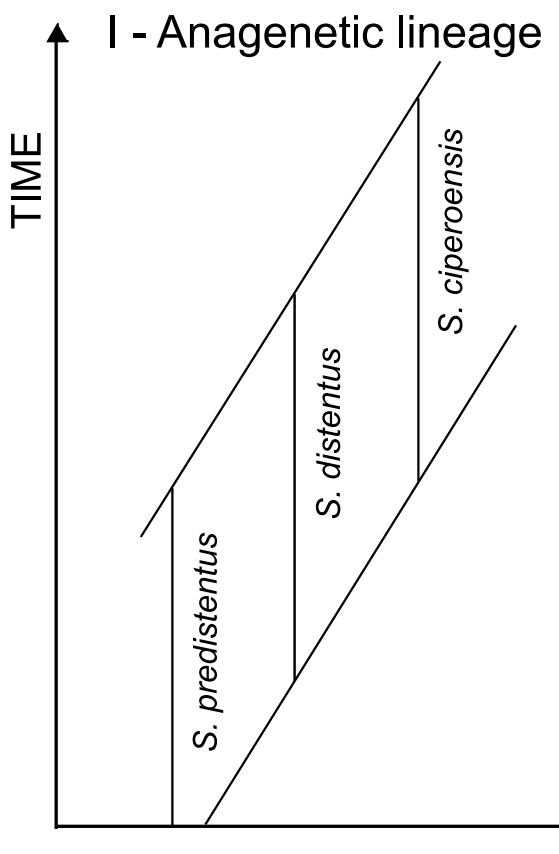

II - Cladogenetic lineage

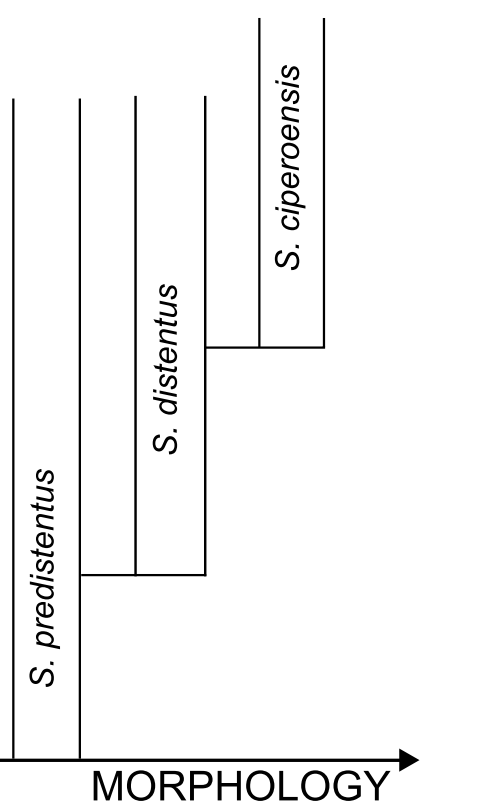

(b)

\section{Sphenolith terminology}

distal

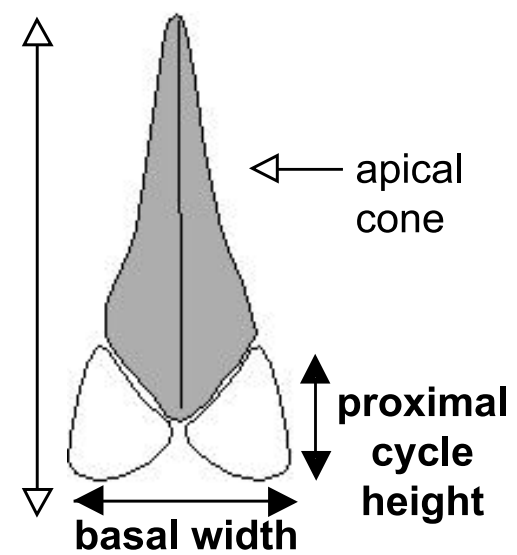

proximal

Fig. 2. (a) The Oligocene sphenolith lineage and two end-member hypotheses on the evolutionary nature of this lineage: (I) anagenetic lineage of intergradational chronospecies; (II) cladogenetic lineage with branching of discrete species. (b) Drawing of Sphenolithus distentus (from Young, 1998) showing morphological features investigated in this study (i.e. basal width and proximal cycle height). Shading indicates the portion of the sphenolith which is dark in cross polars in this orientation.

\begin{tabular}{|c|c|c|c|c|c|c|c|c|c|}
\hline 1 & 199 & 1218 & A & 14 & $\mathrm{H}$ & 3 & 45 & 141.07 & 26.76 \\
\hline 2 & 199 & 1218 & B & 15 & $\mathrm{H}$ & 1 & 135 & 146.57 & 27.08 \\
\hline 4 & 199 & 1218 & B & 16 & $\mathrm{H}$ & 1 & 145 & 157.47 & 27.84 \\
\hline 5 & 199 & 1218 & B & 16 & $\mathrm{H}$ & 5 & 115 & 163.07 & 28.24 \\
\hline 6 & 199 & 1218 & B & 17 & $\mathrm{H}$ & 2 & 15 & 167.83 & 28.54 \\
\hline 9 & 199 & 1218 & A & 18 & $\mathrm{H}$ & 3 & 105 & 184.81 & 29.51 \\
\hline 10 & 199 & 1218 & C & 12 & X & 5 & 65 & 189.93 & 29.86 \\
\hline 11 & 199 & 1218 & B & 21 & X & 4 & 143 & 213.25 & 31.60 \\
\hline 12 & 199 & 1218 & A & 23 & $X$ & 3 & 65 & 232.39 & 33.02 \\
\hline
\end{tabular}

Age is from Pälike et al. (2006; P06).

$\mathrm{T}$, type; Sc, section; rmcd, revised meter composite depth.

Table 1. Samples used for the morphometric study of the Oligocene sphenoliths.

similar and most probably phylogenetically related species follow Roth et al. (1970) and Perch-Nielsen (1985).

Discrimination of the species is conventionally made with the sphenolith orientated at $45^{\circ}$ to the polarization direction. In this orientation the apical cycle shows maximum birefringence and is clearly separated from the proximal cycle by dark extinction lines (Plate 1A). The great variability in this feature provides the main morphological criterion for distinguishing different taxa. In $S$. predistentus the extinction lines run straight across the specimen. In $S$. distentus the extinction lines are inclined, giving a V-shaped appearance. In S. ciperoensis the proximal elements are larger and separated from the spine by curved extinction lines, giving an X-shaped extinction figure (Perch-Nielsen, 1985).

While investigating Oligocene nannofossil biostratigraphy, several nannofossil workers (e.g. Roth et al., 1970; Haq, 1971; Moran \& Watkins, 1988; Okada, 1990; Olafsson \& Villa, 1992) noticed difficulties in identifying the transitional forms from the end-members of the $S$. predistentus, $S$. distentus and $S$. ciperoensis lineage. Transitional forms between $S$. predistentus and $S$. 

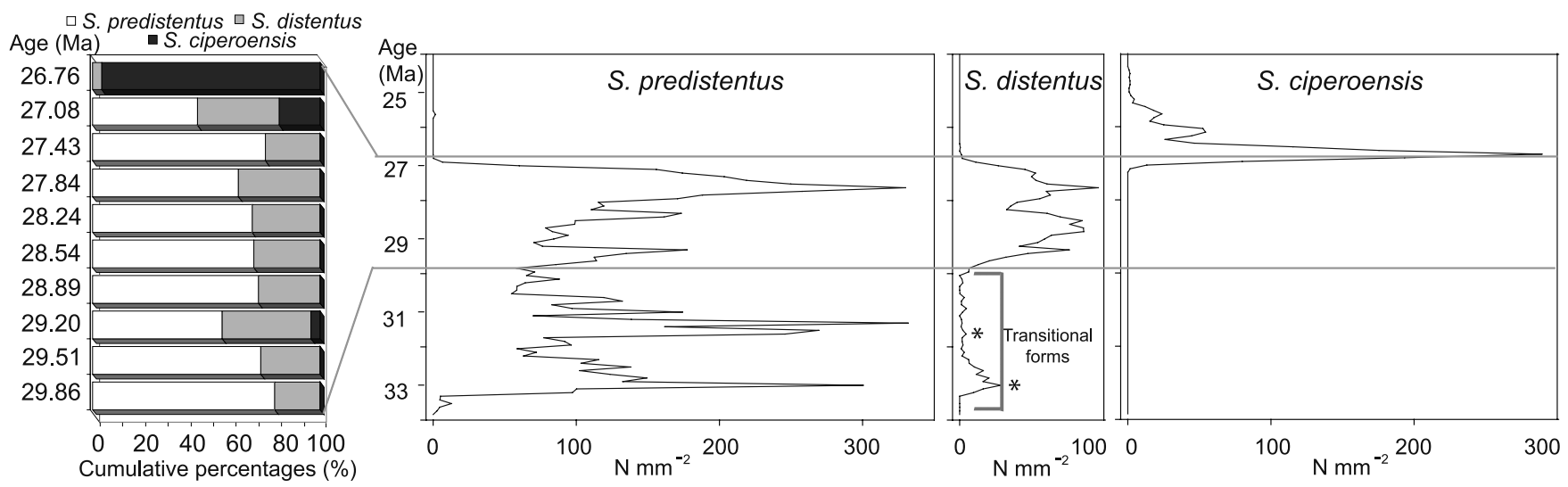

Fig. 3. Left panel: Abundance pattern as cumulative $\%$ of the 100 investigated sphenoliths in each of the ten Oligocene samples used for morphological measurements. Right panels: Abundances (as number of specimens per $\mathrm{mm}^{2}$ of slide surface, $\mathrm{N} \mathrm{mm}^{-2}$ ) of $S$. predistentus, $S$. distentus and S. ciperoensis as identified at Site 1218 (from Blaj et al., 2009). Two additional samples investigated for 'transitional' forms of S. predistentus are indicated with asterisks.

distentus were also observed at Site 1218 (Fig. 3) (Blaj et al., 2009). In these transitional forms, the extinction line between the apical and proximal cycle of the sphenolith varies: it is neither nearly straight, as in $S$. predistentus, nor clearly V-shaped, as in $S$. distentus, when viewed at $45^{\circ}$ to the polarizers. Sphenolithus predistentus apparently grades into $S$. distentus. These intergrading forms between $S$. predistentus and $S$. distentus made placement of the lowest occurrence (LO) of $S$. distentus problematic (Blaj et al., 2009). By contrast, the LO of S. ciperoensis was easy to locate as specimens of $S$. ciperoensis could be clearly distinguished from $S$. distentus, and no transitional forms between the two were observed at Site 1218 (Blaj et al., 2009).

\section{RESULTS AND DISCUSSION}

\section{Sphenolith morphological features in LM and SEM investigation}

The sphenoliths were observed using both LM and SEM. The LM observations (Pl. 1A) confirmed that the majority of specimens could be consistently assigned to species based on their extinction pattern in polarized light: the extinction line between the apical and proximal cycle is straight in $S$. predistentus (Pl. 1A, figs 1-5), V-shaped in S. distentus (Pl. 1A, figs 6-10) and $\mathrm{X}$-shaped in $S$. ciperoensis (Pl. 1A, figs 11-15).

For SEM observations we used samples dominated by Sphenolithus and from each sample a suite of specimens was imaged (75 in total) in order to determine if additional structural differences between the species could be identified. The sphenoliths vary in shape and preservation; most observed specimens appear overgrown and to some extent broken; the apical spines are preserved in only a few specimens. The SEM investigation shows that the proximal cycle forms an open cone, which consists of 9 to 12 individual crystal elements in all investigated species, thus preventing the use of this criterion for taxonomic purposes, whereas the height of the proximal cycle elements varies between different species ( $\mathrm{Pl}$. 1B). In S. predistentus the individual elements are short, lie under the apical cone and have similar height around the entire proximal cycle (Pl. 1B, figs 16-20). This results in a straight extinction line between the apical cycle and proximal column in LM. In $S$. distentus the height of the proximal cycle elements varies, typically with some higher elements (Pl. 1B, figs 21-28); this results in a V-shaped extinction line in LM. In S. ciperoensis (Pl. 1B, figs 29-30) the proximal cycle shows even higher lateral elements, which results in an X-shaped extinction line of this species. The SEM investigations confirm that there are no additional morphological features to distinguish different species; indeed, they are harder to discriminate using the SEM than a LM.

\section{Abundance patterns}

The abundance patterns (expressed as number of specimens per $\mathrm{mm}^{2}$ ) and the sphenolith bioevents (i.e. the LO of $S$. distentus and $S$. ciperoensis and highest occurrence (HO) of $S$. predistentus, $S$. distentus and $S$. ciperoensis) were determined in a previous study at Site 1218 (Blaj et al., 2009), based on LM identification of specimens using conventional criteria. The investigated sphenolith taxa are present throughout the succession but show strong abundance fluctuations throughout their ranges (Fig. 3, right panels). Sphenolithus predistentus dominates the assemblages through most of the analysed core and co-occurs with $S$. distentus in the higher part of its range. The LO of Sphenolithus ciperoensis, as determined at Site 1218 is very close to the HO of S. predistentus and S. distentus (Fig. 3, right panels).

Ten samples with mixed populations of the two or three sphenolith species taken in consideration were chosen for morphometric analysis; from each of these, 100 specimens were selected at random in the LM and imaged. Counts of the abundances of $S$. predistentus, $S$. distentus and $S$. ciperoensis in the ten analysed samples are presented as cumulative frequencies of the 100 specimens measured in each sample and plotted against age (Fig. 3, left panel). The sphenolith assemblages are clearly dominated by $S$. predistentus, which may contribute some bias to the morphometric data since the three sphenolith taxa are not equally represented. Sphenolithus predistentus constitutes about $70 \%$ of the sphenolith assemblage, at least in the first eight samples, but decreases in abundance to around $40 \%$ towards the upper part of the interval where $S$. ciperoensis enters 
Oligocene Sphenolithus evolutionary lineage

A LM Zeiss Axioplan, Magnification 1600x
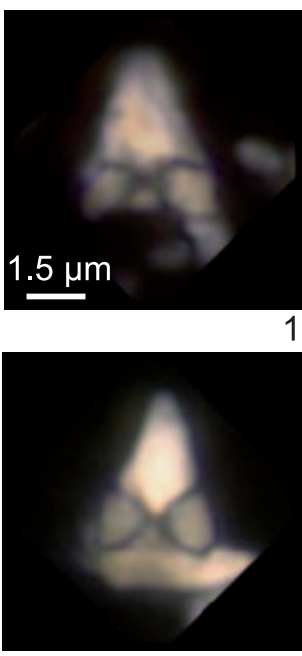

6

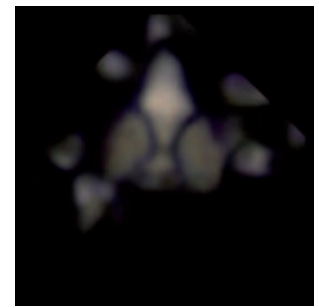

11
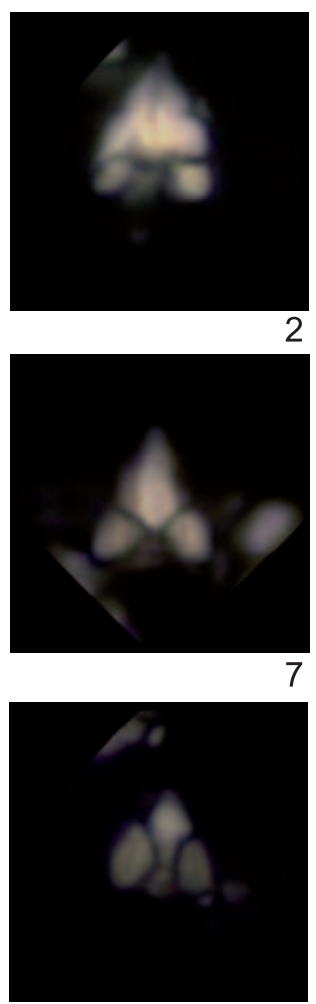

12
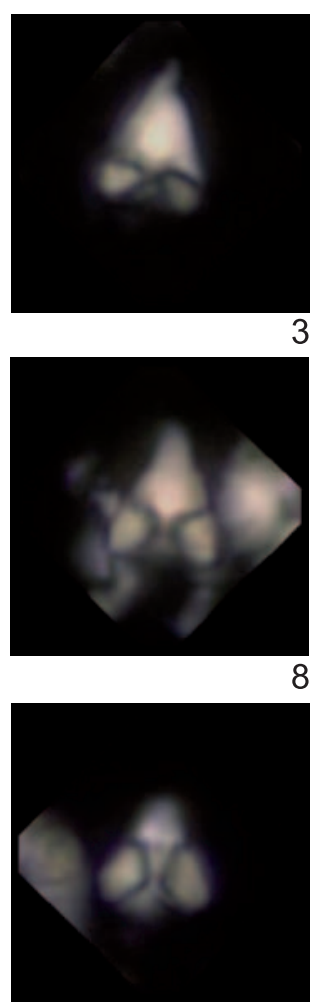

13
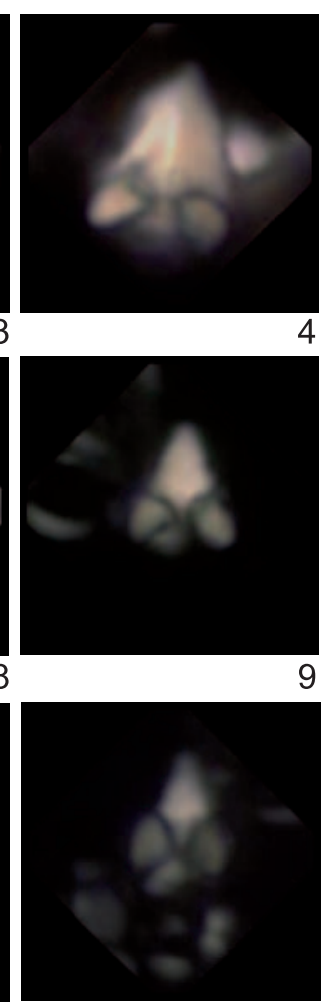

14

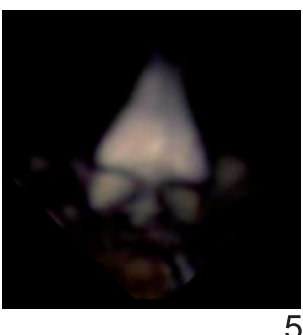

5

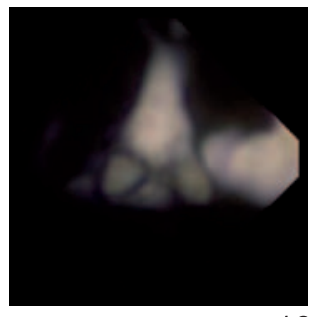

10

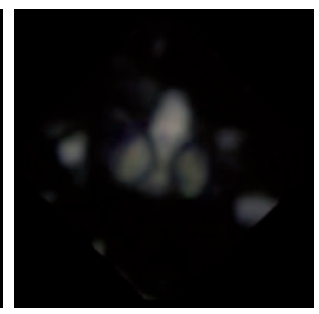

15

B Phillips XL 30 Field Emission SEM, Magnification 5000x
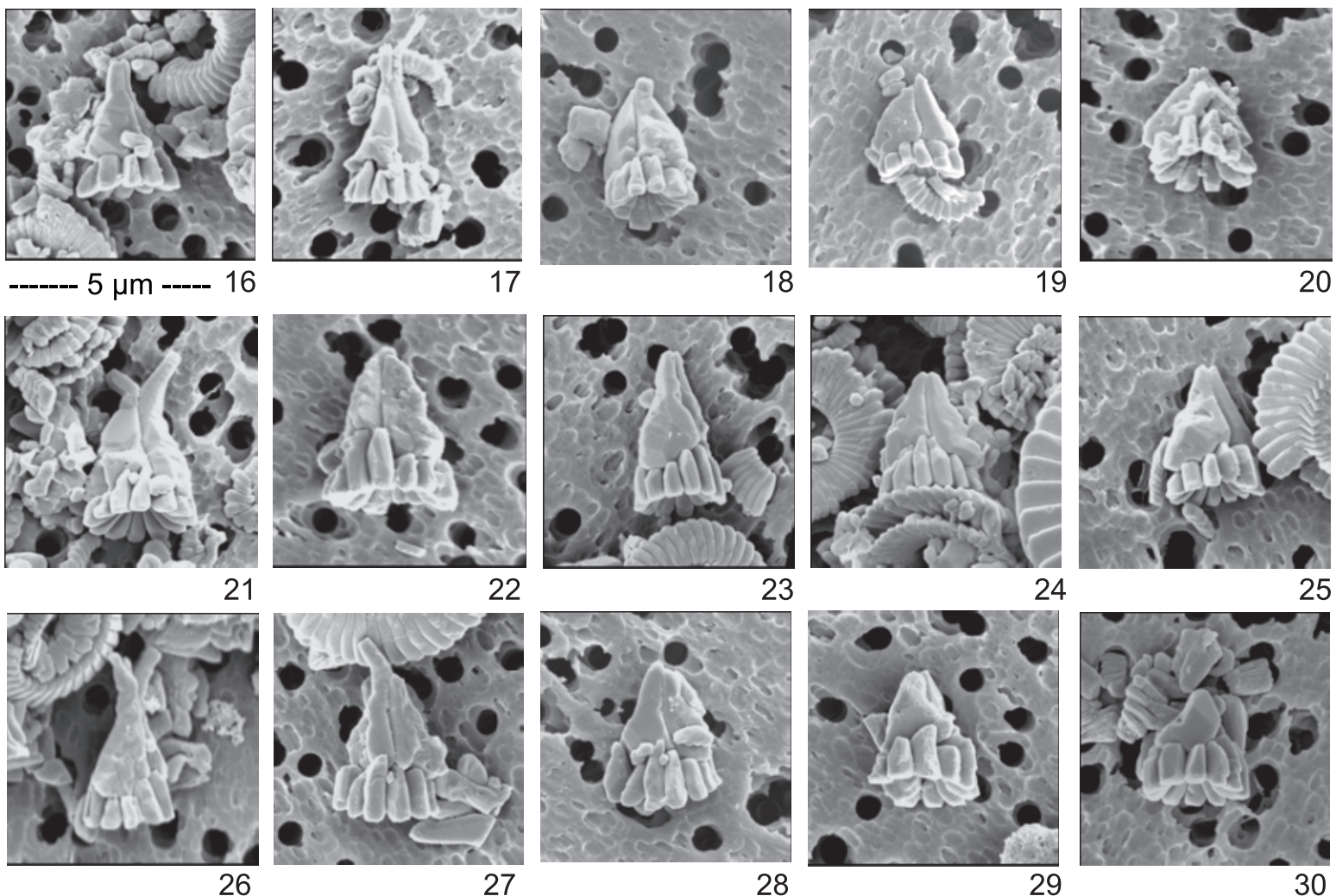

25

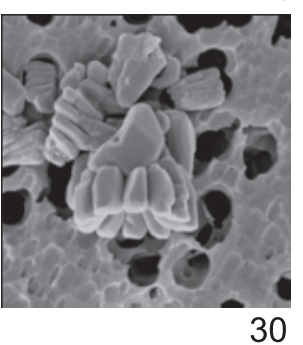



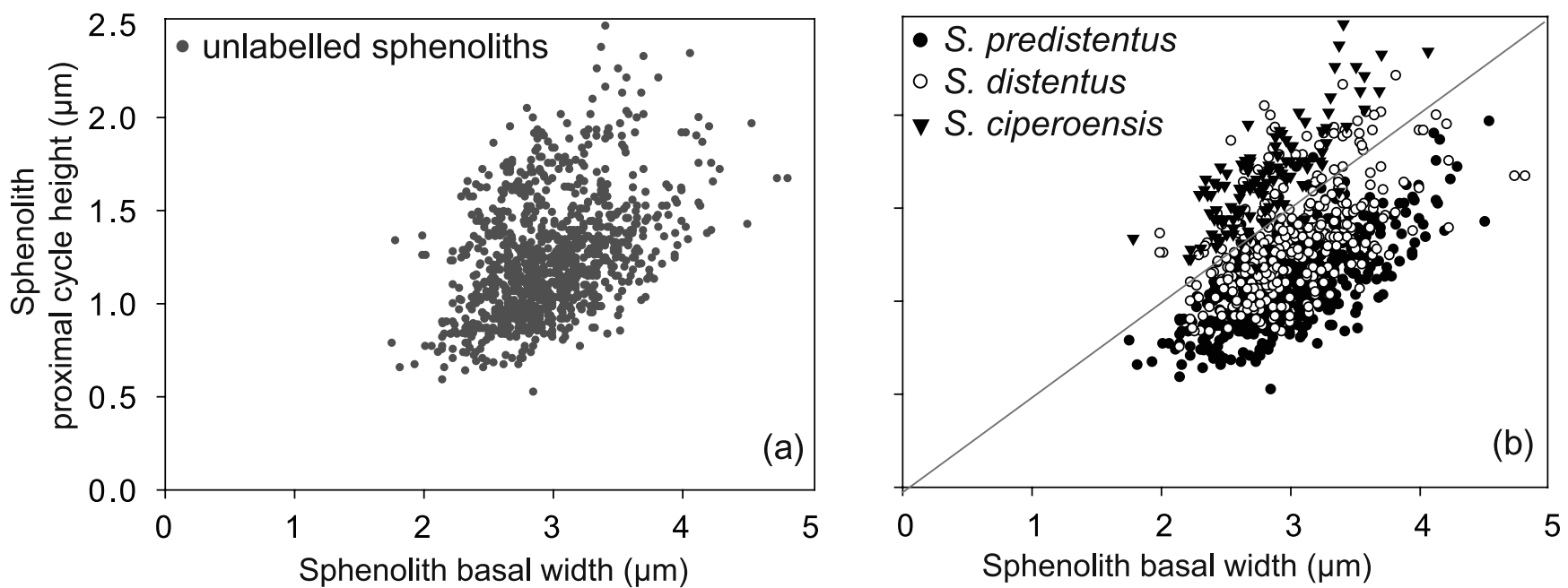

Fig. 4. (a) Relationship between proximal cycle height and basal width in the ten investigated samples of 1000 unlabelled sphenoliths taxa. (b) Scatter plot of proximal cycle height and basal width of the 1000 sphenoliths taxa identified as S. predistentus, S. distentus and S. ciperoensis.

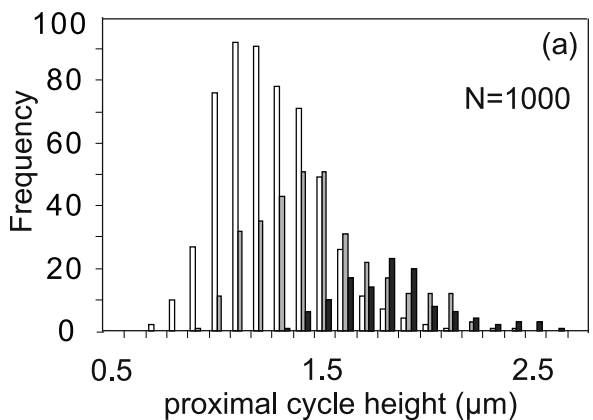

(a)

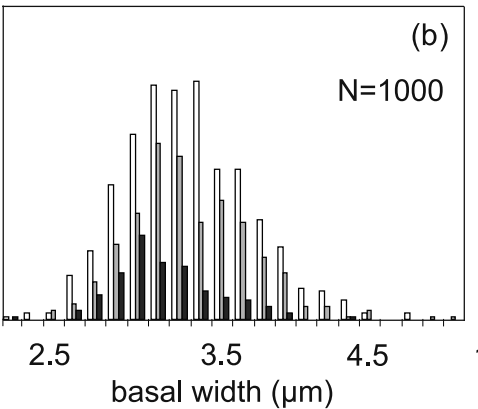

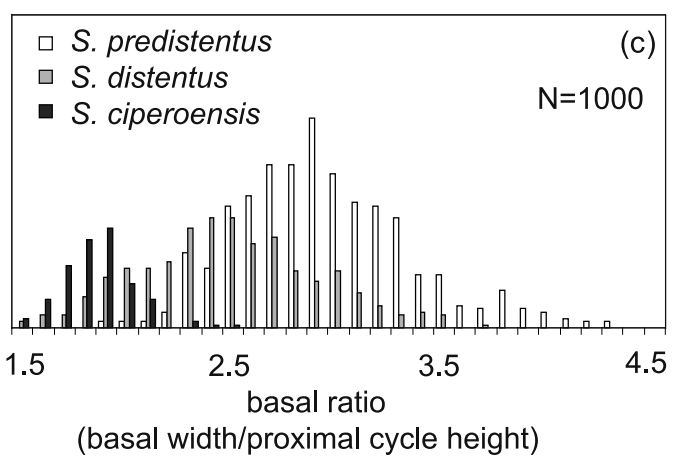

(basal width/proximal cycle height)

Fig. 5. Histograms of (a) sphenolith proximal cycle height, (b) basal width and (c) basal ratio (between basal width and proximal cycle height).

the stratigraphic record. The two additional samples investigated below this interval are dominated by $S$. predistentus, but contain $17-26 \%$ 'transitional' forms (Appendix A).

\section{Sphenolith morphometry}

Sphenolith basal width and proximal cycle height Since the morphological features, which enable us to distinguish the different species, are based primarily on development of the proximal cycle, the basal width and proximal cycle length were measured on each of the 1000 (plus 215) imaged sphenoliths (Appendix A). In a first analysis the relationship between sphenolith basal width and proximal cycle height was investi- gated. The basal width ranges from $1.76 \mu \mathrm{m}$ to $4.81 \mu \mathrm{m}$, while the proximal cycle height varies from $0.52 \mu \mathrm{m}$ to $2.49 \mu \mathrm{m}$ (Fig. 4a). The two parameters show only very weak correlation $\left(r^{2}=0.2\right)$. The scatter diagram of basal width versus proximal cycle height from all samples (Fig. 4a) shows a single large cluster with weak evidence of a frequency minimum around length equals half width. The frequency histograms for the total sphenolith assemblages indicate unimodal distributions of both proximal cycle height (Fig. 5a) and basal width (Fig. 5b), with peaks centred at around $1.1 \mu \mathrm{m}$ and $3 \mu \mathrm{m}$, respectively.

Based on their optical behaviour (i.e. the different shape of the extinction line), the sphenoliths measured in each sample were identified as $S$. distentus, $S$. predistentus and $S$. ciperoensis.

Explanation of Plate 1.

Light and electron micrographs of the three species of Sphenolithus considered here. As discussed, the main difference between the three species is in the height of the proximal cycle relative to the sphenolith width. This affects the shape of the contact between the apical spine and the proximal surface, a feature which is much more obvious in LM than in SEM. (A) LM micrographs. figs 1-5. S. predistentus: 1, sample 1218C 11H-5, 65 cm; 2-3, sample 1218C 12H-5, $65 \mathrm{~cm}$; 4, sample 1218C 11H-5, $65 \mathrm{~cm}$; 5, sample 1218B 16H-1, $145 \mathrm{~cm}$. figs 6-10. S. distentus: 6, sample 1218B 17H-5, $125 \mathrm{~cm}$; 7, sample 1218A 18H-3, $105 \mathrm{~cm} ; \mathbf{8}$, sample 1218C 12H-5, $65 \mathrm{~cm} ; \mathbf{9}$, sample 1218 B 17H-2, $15 \mathrm{~cm} ; \mathbf{1 0}$, sample 1218 B $16 \mathrm{H}-1,145 \mathrm{~cm}$. figs 11-15. S. ciperoensis: sample 1218A 14H-1, $45 \mathrm{~cm}$. (B) SEM micrographs. figs 16-20. S. predistentus: 16, sample 1218A 14H-3, $45 \mathrm{~cm} ; \mathbf{1 7}$, sample 1218A 15H-1, $135 \mathrm{~cm}$; 18-19, sample 1218B 16H-1, $145 \mathrm{~cm}$; 20, sample 1218A 18H-3, $105 \mathrm{~cm}$. figs 21-28. S. distentus: 21, sample 1218A 14H-6, 15 cm; 22, sample 1218A 18H-3, $105 \mathrm{~cm}$; 23, sample 1218A 14H-6, $15 \mathrm{~cm} ; \mathbf{2 4}$, sample 1218B 16H-5, $115 \mathrm{~cm} ; \mathbf{2 5 - 2 6}$, sample $1218 \mathrm{~A} 15 \mathrm{H}-3$, $115 \mathrm{~cm} ; \mathbf{2 7}$, sample 1218B 16H-1, 145 cm; 28, sample 1218A 14H-3, 45 cm. figs 29-30. S. ciperoensis: 29, sample 1218B 18H-3, 105 cm; 30, sample 1218A 15H-3, $115 \mathrm{~cm}$. 

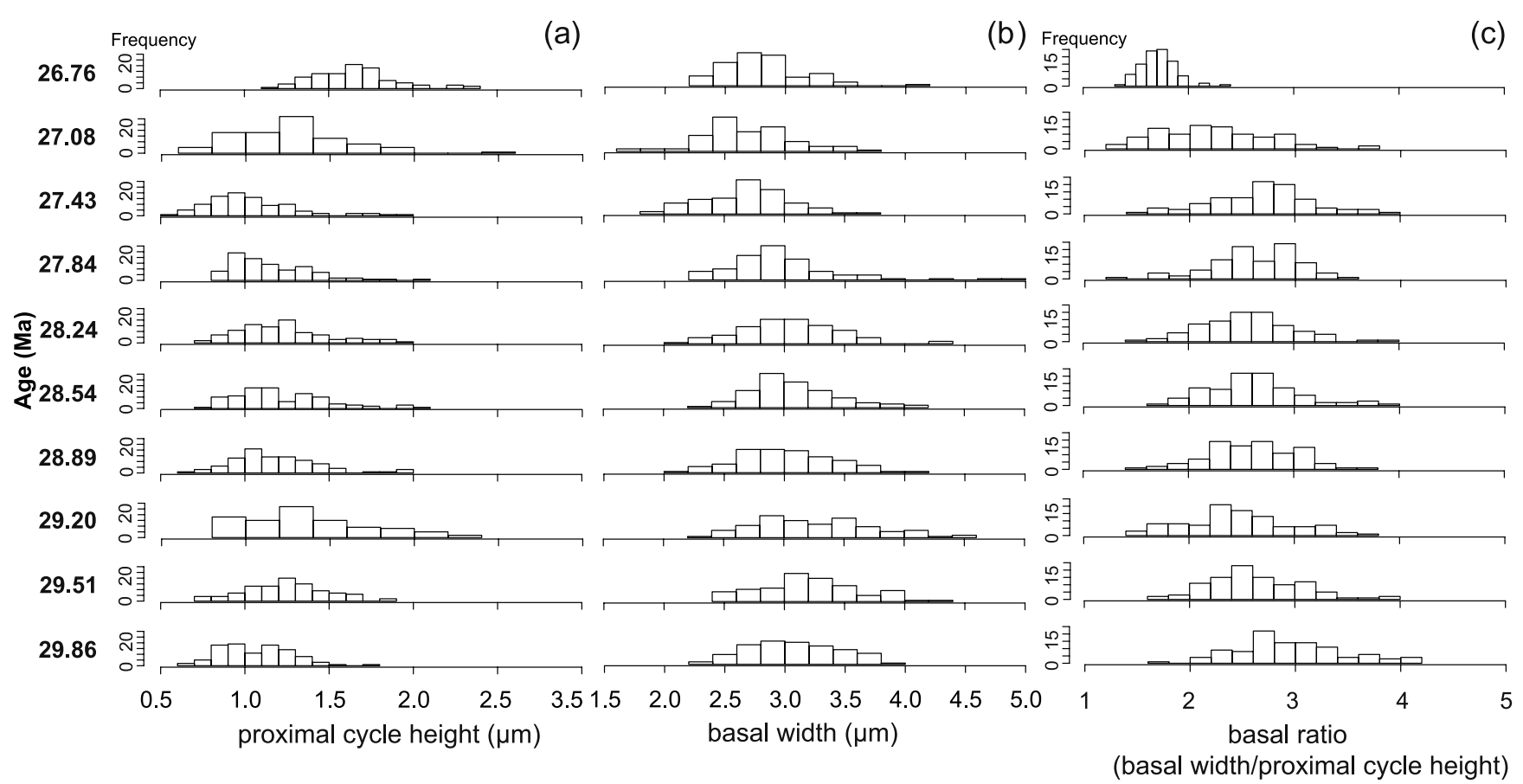

Fig. 6. Histograms of (a) proximal cycle height, (b) basal width and (c) basal ratio in ten different samples arranged in chronological order, i.e. from oldest (bottom) to youngest (top).

When the data points are labelled by species (Fig. 4b), the scatter diagram of all measurements divides into three partially overlapping clusters. The $S$. predistentus and $S$. distentus clusters overlap considerably. Sphenolithus ciperoensis, on the other hand, is rather well separated from the other two taxa at the frequency minimum noted in the labelled plot (oblique line in Fig. 4b). The frequency histograms for the single sphenolith taxa show unimodal distributions of both proximal cycle height (Fig. 5a) and basal width (Fig. 5b) with great overlap between the three species.

The ratio between sphenolith width and proximal height The three data clusters representative of the different sphenolith species (i.e. S. predistentus, S. distentus and S. ciperoensis) have different slopes and positions within the width versus proximal cycle height plot (Fig. 4b), suggesting that the ratio between basal width and proximal cycle height varies between the different taxa. Therefore, in a second analysis the ratio between basal width and proximal cycle height, termed the basal ratio, was investigated within each sphenolith species and sample.

The mean value of the basal ratio (in all samples taken together) is highest in S. predistentus (2.79), followed by $S$. distentus (2.23) and is lowest in S. ciperoensis (1.70). The frequency histogram of the basal ratio shows a bimodal distribution, with a frequency minimum at 2.0 (Fig. 5c). This frequency minimum likely corresponds to the separation of $S$. ciperoensis from $S$. distentus and S. predistentus, as already pointed out in the scatter diagram (Fig. 4b). Moreover, the specimens assigned to $S$. distentus show lower basal ratio values than those assigned to $S$. predistentus, but with extensive overlap.

Unimodal distributions of sphenolith proximal cycle height, basal width and basal ratio are found in each of the top ten investigated samples (Fig. 6). Proximal cycle height and basal width histograms show changing trends with time; in particular, changes in basal width are less distinguishable. Therefore, the basal ratio is mostly influenced by changes in the proximal cycle height (Fig. 6C). The 'transitional' forms within the $S$. predistentus-dominated assemblages from lower stratigraphic levels tend to have smaller basal ratios (Fig. 7).

The basal ratio decreases with time. This decrease is evident both within the sphenolith lineage (Fig. 6c) but also within different sphenolith species (Fig. 8). Notably, S. predistentus and $S$. distentus show very similar patterns of morphological variability over time, and their basal ratios are consistently separated from each other by a relatively constant $\sim 0.5$ difference in the ratio (Fig. 8). This differentiation would not be as obvious when analysing either basal width or proximal cycle height, as the two taxa largely overlap (Fig. 4b). Since the basal ratio varies through time (Table 2), basal width and proximal cycle height must change independently, causing a change in the sphenolith shape.

Changes in the basal ratio values suggest that the $S$. predistentus, S. distentus and S. ciperoensis lineage is composed of three different morphospecies. However, it is important to note that the groups are not distinct in terms of bimodality. Our results reveal time-progressive changes in the basal ratio within the investigated species towards morphospecies with larger proximal cycle height and smaller basal ratios (Fig. 8). These changes are interpreted as indicating evolution within the lineage. If such temporal trends and changes in morphology prove to be globally consistent, the $S$. predistentus, $S$. distentus and $S$. ciperoensis lineage could serve as a valuable example for understanding the evolutionary mechanisms that underlie size and morphology changes in calcareous nannofossils (e.g. Young, 1990; Knappertsbusch, 2000; Henderiks \& Pagani, 2008). In 

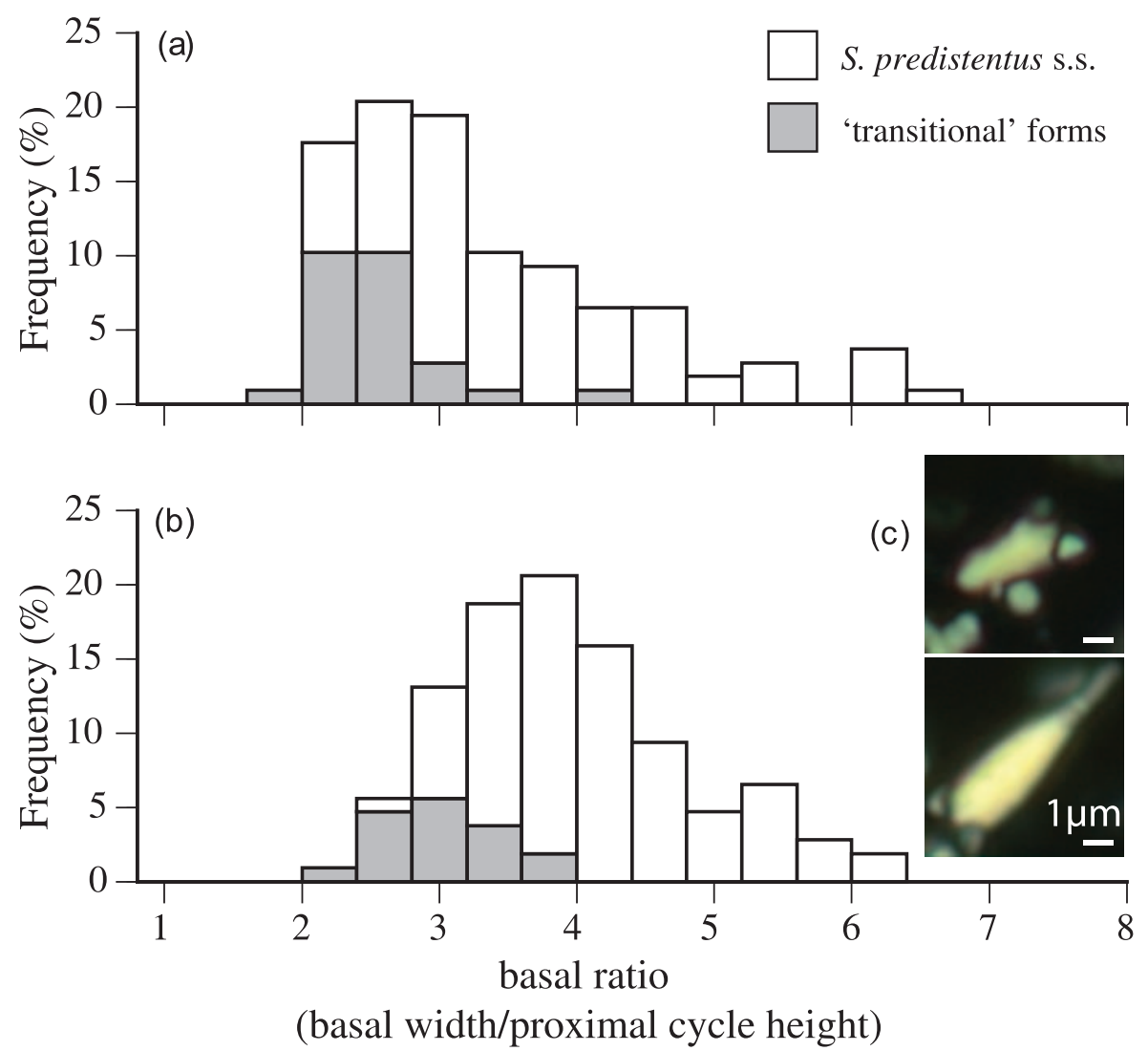

Fig. 7. Histograms of basal ratio in two selected samples containing 'transitional' forms (in grey) and S. predistentus s.s. (in white). (a) Sample 1218B $21 \mathrm{X} 04143 \mathrm{~cm}, 31.60 \mathrm{Ma}$; (b) Sample 1218A 23X $0365 \mathrm{~cm}, 33.02 \mathrm{Ma}$; (c) LM micrographs of transitional forms encountered in (a), taken at $2500 \times$ magnification (scale bar $=1 \mu \mathrm{m}$ ). Note that the extinction line in LM is not straight, as in $S$. predistentus s.s., but slightly curved, although not fully developed in a V-shaped extinction line, which is typical of S. distentus.

order to investigate this issue further, additional investigations of Sphenolithus assemblages from different locations and

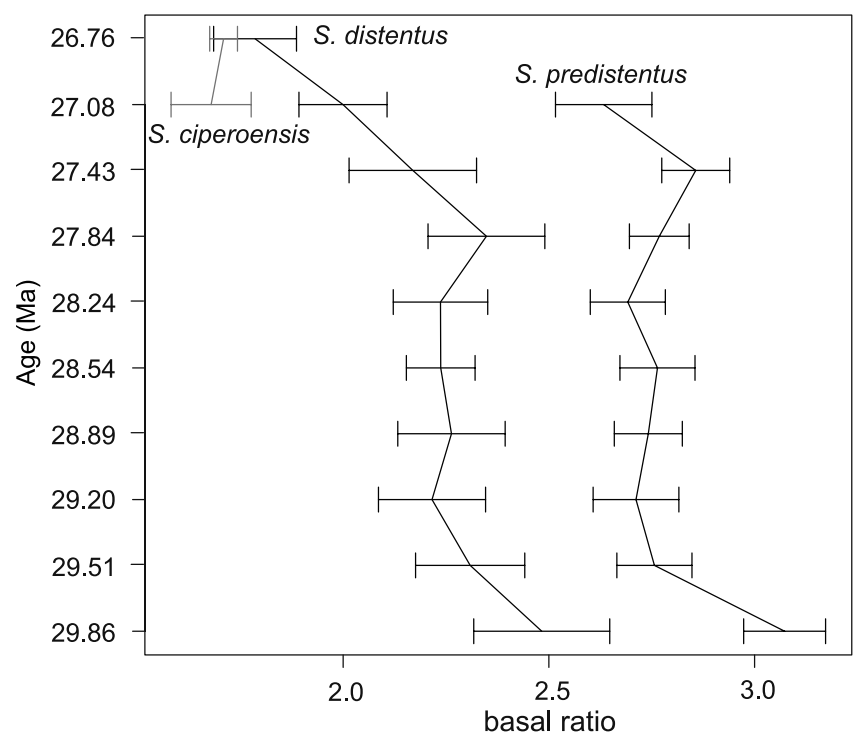

Fig. 8. Plot of changes in time of the basal ratio of $S$. predistentus, $S$. distentus and $S$. ciperoensis; bars represent standard error of the mean; grey shading indicates specimens intergradational between $S$. distentus and $S$. predistentus. extended stratigraphic range - and especially from different latitudes - are needed.

Anagenetic or cladogenetic evolutionary lineage? The main aim of this study was to determine the evolutionary patterns of the Oligocene sphenolith lineage. Based on the stratigraphical range observations (Fig. 3) and the results of morphometric analyses (Figs 4,5 ) of the investigated sphenolith taxa, we propose a combined model for the evolutionary nature of this lineage. The first two members of this lineage (S. predistentus and S. distentus) are difficult to consistently separate either qualitatively or morphometrically and have extensively overlapping stratigraphical ranges, as exemplified by transitional forms between both morphospecies (Fig. 7). These features are characteristic of what we defined as an anagenetic evolutionary model of the lineage. Sphenolithus ciperoensis, on the other hand, is relatively easy to distinguish from the other two species using either qualitative morphological criteria or morphometrics and has a clearly discrete stratigraphical range. In addition, S. ciperoensis has only a very narrow interval of co-occurrence with the other two species; this is a characteristic of a cladogenetic lineage. It would appear obvious that all members of this lineage evolved from each other; however, no transitional forms between $S$. distentus and S. ciperoensis were observed at Site 1218 (Fig. 3, last panel). 


\begin{tabular}{lccccccrrrr}
\hline Species/samples \# & 1 & 2 & 3 & 4 & 5 & 6 & 7 & 8 & 9 \\
\hline S. predistentus & NA & 2.63 & 2.86 & 2.77 & 2.7 & 2.76 & 2.74 & 2.71 & 2.76 \\
S. distentus & 1.79 & 2.00 & 2.17 & 2.34 & 2.23 & 2.23 & 2.26 & 2.21 & 2.31 \\
S. ciperoensis & 1.71 & 1.68 & NA & NA & NA & NA & NA & 1.64 & NA \\
All sphenoliths & 1.71 & 2.23 & 2.69 & 2.62 & 2.56 & 2.61 & 2.61 & 2.47 & 2.64 & NA \\
\end{tabular}

NA, not available

Table 2. Changes in the ratio between sphenolith width and proximal cycle height; units (in $\mu \mathrm{m}$ ) represent the mean value of the different species measurements in each sample.

\section{CONCLUSIONS}

The evolutionary pattern of sphenoliths, as observed in the sedimentary record at Site 1218 in a $3 \mathrm{Ma}$ interval during the Oligocene (29.86-26.76 Ma), indicates that the lineage resulted from successive gradual evolutionary transitions through time.

For the first time, this study provides detailed morphometric evidence for the distinction between three morphospecies, $S$. predistentus, $S$. distentus and $S$. ciperoensis. Our data reveal that the basal ratio (between basal width and proximal cycle height) is distinct between the different morphospecies and can be used to consistently distinguish between the different sphenolith species. The highest basal ratios were found in S. predistentus, lower basal ratios in $S$. distentus and lowest basal ratios in $S$. ciperoensis. Indeed, basal ratios in 'transitional' forms of $S$. predistentus tend be smaller than $S$. predistentus s.s. found in the same assemblages.

Through the time period of co-occurrence of the $S$. distentus and $S$. predistentus species, this basal ratio shows parallel changes in the two species, with an overall trend to lower values, supporting the inference that the two species represent an artificial subdivision of a single anagenetic lineage.

The straightforward morphometric measurements adopted here provide an effective tool for studying evolution within this widespread and biostratigraphically useful lineage and should encourage further exploration by including additional and multiple deep-sea locations.

Based on the stratigraphical range observations and results of the morphometric analyses, we propose a combined model for the evolutionary nature of this lineage: with an anagenetic transition between $S$. predistentus and $S$. distentus and a cladogenetic origin for $S$. ciperoensis. The LO of $S$. distentus appears to represent a shift in morphology within a single phylogenetic lineage without any cladogenesis occurring, whilst the LO of $S$. ciperoensis marks a much more abrupt shift of morphology and probably a cladogenetic event shortly followed by extinction of the ancestral species.

\section{ACKNOWLEGEMENTS}

This research received support from the SYNTHESYS Project (http://www.synthesys.info/) financed by the European Community Research Infrastructure Action under the FP6 Structuring the European Research Area Programme. The assistance of Lauren Howard of the NHM EMMA unit is gratefully acknowledged, as are the valuable comments of Jan Backman. The authors thank the reviewer Claudia Agnini, an anonymous reviewer and the editor John Gregory for constructive comments and remarks.

\section{Manuscript received 9 February 2009 \\ Manuscript accepted 6 March 2010}

\section{APPENDIX A: MEASUREMENTS OF SPECIMENS FROM THE S. PREDISTENSUS-DISTENTUS- CIPEROENSIS GROUP}

\begin{tabular}{|c|c|c|c|c|c|}
\hline $\begin{array}{l}\text { Sample } \\
\text { \# }\end{array}$ & $\begin{array}{l}\text { Age } \\
(\mathrm{Ma})\end{array}$ & $\begin{array}{l}\text { Width } \\
(\mu \mathrm{m})\end{array}$ & $\begin{array}{l}\text { Height } \\
(\mu \mathrm{m})\end{array}$ & $\begin{array}{l}\text { Ratio } \\
\text { W/H }\end{array}$ & Species ID \\
\hline 1 & 26.76 & 2.51 & 1.38 & 1.82 & S. distentus \\
\hline 1 & 26.76 & 2.88 & 1.56 & 1.85 & S. distentus \\
\hline 1 & 26.76 & 2.95 & 1.60 & 1.84 & S. distentus \\
\hline 1 & 26.76 & 2.91 & 1.78 & 1.63 & S. distentus \\
\hline 1 & 26.76 & 2.80 & 1.49 & 1.88 & S. ciperoensis \\
\hline 1 & 26.76 & 2.55 & 1.39 & 1.84 & S. ciperoensis \\
\hline 1 & 26.76 & 2.69 & 1.75 & 1.53 & S. ciperoensis \\
\hline 1 & 26.76 & 2.67 & 1.70 & 1.57 & S. ciperoensis \\
\hline 1 & 26.76 & 2.78 & 1.57 & 1.77 & S. ciperoensis \\
\hline 1 & 26.76 & 2.67 & 1.95 & 1.37 & S. ciperoensis \\
\hline 1 & 26.76 & 2.57 & 1.49 & 1.73 & S. ciperoensis \\
\hline 1 & 26.76 & 2.69 & 1.77 & 1.52 & S. ciperoensis \\
\hline 1 & 26.76 & 2.82 & 1.42 & 1.98 & S. ciperoensis \\
\hline 1 & 26.76 & 2.69 & 1.46 & 1.84 & S. ciperoensis \\
\hline 1 & 26.76 & 2.90 & 1.52 & 1.90 & S. ciperoensis \\
\hline 1 & 26.76 & 2.83 & 1.70 & 1.66 & S. ciperoensis \\
\hline 1 & 26.76 & 2.44 & 1.62 & 1.51 & S. ciperoensis \\
\hline 1 & 26.76 & 2.34 & 1.65 & 1.42 & S. ciperoensis \\
\hline 1 & 26.76 & 2.88 & 1.88 & 1.53 & S. ciperoensis \\
\hline 1 & 26.76 & 2.67 & 1.72 & 1.55 & S. ciperoensis \\
\hline 1 & 26.76 & 3.50 & 2.26 & 1.55 & S. ciperoensis \\
\hline 1 & 26.76 & 3.01 & 1.83 & 1.64 & S. ciperoensis \\
\hline 1 & 26.76 & 2.49 & 1.62 & 1.54 & S. ciperoensis \\
\hline 1 & 26.76 & 3.37 & 1.59 & 2.12 & S. ciperoensis \\
\hline 1 & 26.76 & 3.57 & 2.03 & 1.76 & S. ciperoensis \\
\hline 1 & 26.76 & 2.90 & 1.72 & 1.69 & S. ciperoensis \\
\hline 1 & 26.76 & 2.77 & 1.62 & 1.71 & S. ciperoensis \\
\hline 1 & 26.76 & 3.00 & 1.83 & 1.63 & S. ciperoensis \\
\hline 1 & 26.76 & 2.67 & 1.74 & 1.54 & S. ciperoensis \\
\hline 1 & 26.76 & 2.23 & 1.28 & 1.74 & S. ciperoensis \\
\hline 1 & 26.76 & 2.80 & 1.62 & 1.73 & S. ciperoensis \\
\hline 1 & 26.76 & 3.13 & 1.75 & 1.79 & S. ciperoensis \\
\hline 1 & 26.76 & 2.39 & 1.36 & 1.76 & S. ciperoensis \\
\hline 1 & 26.76 & 2.78 & 1.60 & 1.73 & S. ciperoensis \\
\hline 1 & 26.76 & 2.59 & 1.49 & 1.74 & S. ciperoensis \\
\hline 1 & 26.76 & 3.11 & 1.44 & 2.16 & S. ciperoensis \\
\hline 1 & 26.76 & 2.42 & 1.29 & 1.87 & S. ciperoensis \\
\hline 1 & 26.76 & 2.83 & 1.51 & 1.88 & S. ciperoensis \\
\hline 1 & 26.76 & 3.11 & 1.97 & 1.58 & S. ciperoensis \\
\hline 1 & 26.76 & 2.46 & 1.72 & 1.43 & S. ciperoensis \\
\hline 1 & 26.76 & 3.00 & 1.75 & 1.71 & S. ciperoensis \\
\hline
\end{tabular}

Table A1. Measurements of 100 randomly selected from 10 samples of the $S$. predistensus-distentus-ciperoensis group. 
T. Blaj et al.

\begin{tabular}{|c|c|c|c|c|c|}
\hline $\begin{array}{l}\text { Sample } \\
\text { \# }\end{array}$ & $\begin{array}{c}\text { Age } \\
(\mathrm{Ma})\end{array}$ & $\begin{array}{l}\text { Width } \\
(\mu \mathrm{m})\end{array}$ & $\begin{array}{c}\text { Height } \\
(\mu \mathrm{m})\end{array}$ & $\begin{array}{l}\text { Ratio } \\
\text { W/H }\end{array}$ & Species ID \\
\hline 1 & 26.76 & 2.82 & 1.64 & 1.72 & S. ciperoensis \\
\hline 1 & 26.76 & 2.60 & 1.60 & 1.62 & S. ciperoensis \\
\hline 1 & 26.76 & 2.60 & 1.56 & 1.67 & S. ciperoensis \\
\hline 1 & 26.76 & 3.34 & 2.26 & 1.48 & S. ciperoensis \\
\hline 1 & 26.76 & 2.62 & 1.60 & 1.63 & S. ciperoensis \\
\hline 1 & 26.76 & 2.62 & 1.74 & 1.51 & S. ciperoensis \\
\hline 1 & 26.76 & 2.36 & 1.57 & 1.50 & S. ciperoensis \\
\hline 1 & 26.76 & 2.73 & 1.65 & 1.65 & S. ciperoensis \\
\hline 1 & 26.76 & 2.46 & 1.33 & 1.85 & S. ciperoensis \\
\hline 1 & 26.76 & 2.62 & 1.31 & 2.00 & S. ciperoensis \\
\hline 1 & 26.76 & 3.24 & 1.74 & 1.87 & S. ciperoensis \\
\hline 1 & 26.76 & 2.91 & 1.92 & 1.52 & S. ciperoensis \\
\hline 1 & 26.76 & 2.21 & 1.23 & 1.80 & S. ciperoensis \\
\hline 1 & 26.76 & 2.51 & 1.69 & 1.49 & S. ciperoensis \\
\hline 1 & 26.76 & 3.28 & 1.93 & 1.69 & S. ciperoensis \\
\hline 1 & 26.76 & 3.24 & 1.92 & 1.69 & S. ciperoensis \\
\hline 1 & 26.76 & 2.47 & 1.42 & 1.74 & S. ciperoensis \\
\hline 1 & 26.76 & 2.95 & 1.52 & 1.94 & S. ciperoensis \\
\hline 1 & 26.76 & 2.62 & 1.60 & 1.63 & S. ciperoensis \\
\hline 1 & 26.76 & 2.23 & 1.23 & 1.81 & S. ciperoensis \\
\hline 1 & 26.76 & 2.49 & 1.44 & 1.73 & S. ciperoensis \\
\hline 1 & 26.76 & 2.96 & 1.65 & 1.79 & S. ciperoensis \\
\hline 1 & 26.76 & 2.42 & 1.49 & 1.63 & S. ciperoensis \\
\hline 1 & 26.76 & 2.73 & 1.18 & 2.32 & S. ciperoensis \\
\hline 1 & 26.76 & 2.55 & 1.36 & 1.88 & S. ciperoensis \\
\hline 1 & 26.76 & 2.51 & 1.36 & 1.84 & S. ciperoensis \\
\hline 1 & 26.76 & 2.96 & 1.75 & 1.69 & S. ciperoensis \\
\hline 1 & 26.76 & 3.00 & 1.67 & 1.79 & S. ciperoensis \\
\hline 1 & 26.76 & 2.62 & 1.59 & 1.65 & S. ciperoensis \\
\hline 1 & 26.76 & 2.93 & 1.69 & 1.74 & S. ciperoensis \\
\hline 1 & 26.76 & 3.06 & 2.01 & 1.52 & S. ciperoensis \\
\hline 1 & 26.76 & 2.93 & 1.90 & 1.54 & S. ciperoensis \\
\hline 1 & 26.76 & 2.96 & 1.87 & 1.59 & S. ciperoensis \\
\hline 1 & 26.76 & 2.42 & 1.34 & 1.80 & S. ciperoensis \\
\hline 1 & 26.76 & 2.37 & 1.47 & 1.61 & S. ciperoensis \\
\hline 1 & 26.76 & 3.13 & 1.72 & 1.82 & S. ciperoensis \\
\hline 1 & 26.76 & 2.41 & 1.64 & 1.47 & S. ciperoensis \\
\hline 1 & 26.76 & 2.69 & 1.60 & 1.67 & S. ciperoensis \\
\hline 1 & 26.76 & 2.55 & 1.44 & 1.77 & S. ciperoensis \\
\hline 1 & 26.76 & 3.08 & 1.75 & 1.76 & S. ciperoensis \\
\hline 1 & 26.76 & 2.78 & 1.42 & 1.95 & S. ciperoensis \\
\hline 1 & 26.76 & 4.06 & 2.34 & 1.73 & S. ciperoensis \\
\hline 1 & 26.76 & 2.72 & 1.64 & 1.66 & S. ciperoensis \\
\hline 1 & 26.76 & 3.57 & 2.21 & 1.61 & S. ciperoensis \\
\hline 1 & 26.76 & 3.24 & 1.80 & 1.80 & S. ciperoensis \\
\hline 1 & 26.76 & 3.23 & 1.75 & 1.84 & S. ciperoensis \\
\hline 1 & 26.76 & 2.29 & 1.57 & 1.46 & S. ciperoensis \\
\hline 1 & 26.76 & 2.67 & 1.38 & 1.94 & S. ciperoensis \\
\hline 1 & 26.76 & 2.90 & 1.78 & 1.62 & S. ciperoensis \\
\hline 1 & 26.76 & 2.62 & 1.59 & 1.65 & S. ciperoensis \\
\hline 1 & 26.76 & 2.78 & 1.69 & 1.65 & S. ciperoensis \\
\hline 1 & 26.76 & 3.29 & 2.01 & 1.63 & S. ciperoensis \\
\hline 1 & 26.76 & 2.75 & 1.59 & 1.73 & S. ciperoensis \\
\hline 1 & 26.76 & 2.87 & 1.65 & 1.73 & S. ciperoensis \\
\hline 1 & 26.76 & 3.28 & 1.85 & 1.77 & S. ciperoensis \\
\hline 1 & 26.76 & 2.80 & 1.49 & 1.88 & S. ciperoensis \\
\hline 1 & 26.76 & 2.54 & 1.51 & 1.68 & S. ciperoensis \\
\hline 1 & 26.76 & 2.69 & 1.34 & 2.00 & S. ciperoensis \\
\hline 1 & 26.76 & 3.37 & 2.37 & 1.42 & S. ciperoensis \\
\hline 2 & 27.08 & 3.17 & 1.23 & 2.57 & S. predistentus \\
\hline 2 & 27.08 & 2.44 & 0.86 & 2.82 & S. predistentus \\
\hline 2 & 27.08 & 2.46 & 0.86 & 2.85 & S. predistentus \\
\hline 2 & 27.08 & 2.78 & 0.97 & 2.86 & S. predistentus \\
\hline
\end{tabular}

Table A1. Continued.

\begin{tabular}{|c|c|c|c|c|c|}
\hline $\begin{array}{l}\text { Sample } \\
\text { \# }\end{array}$ & $\begin{array}{l}\text { Age } \\
(\mathrm{Ma})\end{array}$ & $\begin{array}{l}\text { Width } \\
(\mu \mathrm{m})\end{array}$ & $\begin{array}{c}\text { Height } \\
(\mu \mathrm{m})\end{array}$ & $\begin{array}{l}\text { Ratio } \\
\text { W/H }\end{array}$ & Species ID \\
\hline 2 & 27.08 & 2.41 & 1.10 & 2.19 & S. predistentus \\
\hline 2 & 27.08 & 3.30 & 1.05 & 3.15 & S. predistentus \\
\hline 2 & 27.08 & 2.72 & 0.92 & 2.97 & S. predistentus \\
\hline 2 & 27.08 & 2.59 & 1.23 & 2.11 & S. predistentus \\
\hline 2 & 27.08 & 2.38 & 0.84 & 2.84 & S. predistentus \\
\hline 2 & 27.08 & 3.07 & 0.92 & 3.34 & S. predistentus \\
\hline 2 & 27.08 & 2.38 & 1.00 & 2.39 & S. predistentus \\
\hline 2 & 27.08 & 3.07 & 1.07 & 2.85 & S. predistentus \\
\hline 2 & 27.08 & 2.93 & 1.15 & 2.55 & S. predistentus \\
\hline 2 & 27.08 & 3.35 & 1.55 & 2.17 & S. predistentus \\
\hline 2 & 27.08 & 1.76 & 0.79 & 2.23 & S. predistentus \\
\hline 2 & 27.08 & 2.54 & 1.10 & 2.31 & S. predistentus \\
\hline 2 & 27.08 & 2.36 & 0.76 & 3.10 & S. predistentus \\
\hline 2 & 27.08 & 2.28 & 1.02 & 2.23 & S. predistentus \\
\hline 2 & 27.08 & 2.41 & 0.86 & 2.79 & S. predistentus \\
\hline 2 & 27.08 & 2.33 & 0.73 & 3.18 & S. predistentus \\
\hline 2 & 27.08 & 2.91 & 0.97 & 3.00 & S. predistentus \\
\hline 2 & 27.08 & 3.25 & 1.15 & 2.82 & S. predistentus \\
\hline 2 & 27.08 & 2.91 & 1.26 & 2.31 & S. predistentus \\
\hline 2 & 27.08 & 2.46 & 0.66 & 3.76 & S. predistentus \\
\hline 2 & 27.08 & 3.07 & 1.21 & 2.54 & S. predistentus \\
\hline 2 & 27.08 & 3.07 & 1.26 & 2.44 & S. predistentus \\
\hline 2 & 27.08 & 2.80 & 1.07 & 2.61 & S. predistentus \\
\hline 2 & 27.08 & 2.96 & 1.36 & 2.17 & S. predistentus \\
\hline 2 & 27.08 & 2.59 & 0.94 & 2.75 & S. predistentus \\
\hline 2 & 27.08 & 2.52 & 0.84 & 3.00 & S. predistentus \\
\hline 2 & 27.08 & 2.57 & 1.21 & 2.13 & S. predistentus \\
\hline 2 & 27.08 & 2.78 & 1.31 & 2.12 & S. predistentus \\
\hline 2 & 27.08 & 3.41 & 1.34 & 2.55 & S. predistentus \\
\hline 2 & 27.08 & 2.54 & 0.92 & 2.77 & S. predistentus \\
\hline 2 & 27.08 & 2.80 & 1.21 & 2.33 & S. predistentus \\
\hline 2 & 27.08 & 2.65 & 0.94 & 2.81 & S. predistentus \\
\hline 2 & 27.08 & 2.38 & 0.89 & 2.68 & S. predistentus \\
\hline 2 & 27.08 & 2.86 & 1.21 & 2.37 & S. predistentus \\
\hline 2 & 27.08 & 2.93 & 1.36 & 2.15 & S. predistentus \\
\hline 2 & 27.08 & 2.67 & 1.15 & 2.32 & S. predistentus \\
\hline 2 & 27.08 & 2.49 & 1.05 & 2.38 & S. predistentus \\
\hline 2 & 27.08 & 2.54 & 0.92 & 2.77 & S. predistentus \\
\hline 2 & 27.08 & 2.59 & 1.18 & 2.20 & S. predistentus \\
\hline 2 & 27.08 & 2.88 & 1.15 & 2.50 & S. predistentus \\
\hline 2 & 27.08 & 2.15 & 0.89 & 2.41 & S. predistentus \\
\hline 2 & 27.08 & 2.54 & 0.68 & 3.73 & S. predistentus \\
\hline 2 & 27.08 & 2.46 & 0.94 & 2.61 & S. distentus \\
\hline 2 & 27.08 & 3.56 & 1.81 & 1.97 & S. distentus \\
\hline 2 & 27.08 & 2.93 & 1.68 & 1.75 & S. distentus \\
\hline 2 & 27.08 & 2.83 & 1.60 & 1.77 & S. distentus \\
\hline 2 & 27.08 & 2.83 & 1.52 & 1.86 & S. distentus \\
\hline 2 & 27.08 & 2.31 & 0.84 & 2.75 & S. distentus \\
\hline 2 & 27.08 & 2.44 & 1.47 & 1.66 & S. distentus \\
\hline 2 & 27.08 & 2.52 & 1.18 & 2.13 & S. distentus \\
\hline 2 & 27.08 & 2.70 & 1.31 & 2.06 & S. distentus \\
\hline 2 & 27.08 & 1.99 & 1.36 & 1.46 & S. distentus \\
\hline 2 & 27.08 & 2.23 & 1.10 & 2.02 & S. distentus \\
\hline 2 & 27.08 & 2.02 & 1.26 & 1.60 & S. distentus \\
\hline 2 & 27.08 & 2.62 & 1.31 & 2.00 & S. distentus \\
\hline 2 & 27.08 & 2.78 & 1.44 & 1.93 & S. distentus \\
\hline 2 & 27.08 & 2.41 & 1.15 & 2.09 & S. distentus \\
\hline 2 & 27.08 & 2.54 & 1.86 & 1.37 & S. distentus \\
\hline 2 & 27.08 & 2.44 & 1.21 & 2.02 & S. distentus \\
\hline 2 & 27.08 & 3.35 & 1.36 & 2.46 & S. distentus \\
\hline 2 & 27.08 & 2.57 & 1.26 & 2.04 & S. distentus \\
\hline 2 & 27.08 & 2.59 & 1.36 & 1.90 & S. distentus \\
\hline 2 & 27.08 & 3.04 & 1.34 & 2.27 & S. distentus \\
\hline
\end{tabular}

Table A1. Continued. 


\begin{tabular}{|c|c|c|c|c|c|c|c|c|c|c|c|}
\hline $\begin{array}{l}\text { Sample } \\
\#\end{array}$ & $\begin{array}{l}\text { Age } \\
\text { (Ma) }\end{array}$ & $\begin{array}{c}\text { Width } \\
(\mu \mathrm{m})\end{array}$ & $\begin{array}{l}\text { Height } \\
(\mu \mathrm{m})\end{array}$ & $\begin{array}{c}\text { Ratio } \\
\text { W/H }\end{array}$ & Species ID & $\begin{array}{l}\text { Sample } \\
\#\end{array}$ & $\begin{array}{l}\text { Age } \\
\text { (Ma) }\end{array}$ & $\begin{array}{l}\text { Width } \\
(\mu \mathrm{m})\end{array}$ & $\begin{array}{l}\text { Height } \\
(\mu \mathrm{m})\end{array}$ & $\begin{array}{c}\text { Ratio } \\
\text { W/H }\end{array}$ & Species ID \\
\hline 2 & 27.08 & 2.54 & 1.21 & 2.11 & S. distentus & 3 & 27.43 & 2.54 & 1.08 & 2.35 & S. predistentus \\
\hline 2 & 27.08 & 2.65 & 1.23 & 2.15 & S. distentus & 3 & 27.43 & 2.69 & 1.06 & 2.52 & S. predistentus \\
\hline 2 & 27.08 & 3.64 & 1.49 & 2.44 & S. distentus & 3 & 27.43 & 3.37 & 1.41 & 2.40 & S. predistentus \\
\hline 2 & 27.08 & 2.72 & 1.21 & 2.26 & S. distentus & 3 & 27.43 & 2.98 & 1.00 & 2.98 & S. predistentus \\
\hline 2 & 27.08 & 2.36 & 1.31 & 1.80 & S. distentus & 3 & 27.43 & 2.16 & 0.84 & 2.59 & S. predistentus \\
\hline 2 & 27.08 & 2.46 & 1.10 & 2.24 & S. distentus & 3 & 27.43 & 3.14 & 1.21 & 2.59 & S. predistentus \\
\hline 2 & 27.08 & 2.65 & 1.34 & 1.98 & S. distentus & 3 & 27.43 & 2.64 & 1.03 & 2.56 & S. predistentus \\
\hline 2 & 27.08 & 2.33 & 1.26 & 1.85 & S. distentus & 3 & 27.43 & 2.65 & 0.92 & 2.89 & S. predistentus \\
\hline 2 & 27.08 & 2.86 & 1.91 & 1.49 & S. distentus & 3 & 27.43 & 2.42 & 0.88 & 2.74 & S. predistentus \\
\hline 2 & 27.08 & 2.83 & 1.28 & 2.20 & S. distentus & 3 & 27.43 & 2.64 & 0.88 & 2.98 & S. predistentus \\
\hline 2 & 27.08 & 2.80 & 1.52 & 1.84 & S. distentus & 3 & 27.43 & 2.77 & 0.92 & 3.02 & S. predistentus \\
\hline 2 & 27.08 & 1.99 & 1.26 & 1.58 & S. distentus & 3 & 27.43 & 2.33 & 0.84 & 2.78 & S. predistentus \\
\hline 2 & 27.08 & 2.65 & 1.70 & 1.55 & S. distentus & 3 & 27.43 & 2.73 & 0.87 & 3.15 & S. predistentus \\
\hline 2 & 27.08 & 2.88 & 1.18 & 2.44 & S. distentus & 3 & 27.43 & 2.21 & 0.84 & 2.65 & S. predistentus \\
\hline 2 & 27.08 & 2.70 & 1.18 & 2.29 & S. distentus & 3 & 27.43 & 2.33 & 0.87 & 2.68 & S. predistentus \\
\hline 2 & 27.08 & 2.65 & 1.76 & 1.51 & S. ciperoensis & 3 & 27.43 & 1.82 & 0.66 & 2.78 & S. predistentus \\
\hline 2 & 27.08 & 2.88 & 1.83 & 1.57 & S. ciperoensis & 3 & 27.43 & 2.01 & 0.77 & 2.62 & S. predistentus \\
\hline 2 & 27.08 & 2.91 & 1.70 & 1.71 & S. ciperoensis & 3 & 27.43 & 2.82 & 0.84 & 3.37 & S. predistentus \\
\hline 2 & 27.08 & 2.62 & 1.49 & 1.75 & S. ciperoensis & 3 & 27.43 & 2.44 & 0.75 & 3.24 & S. predistentus \\
\hline 2 & 27.08 & 1.78 & 1.34 & 1.33 & S. ciperoensis & 3 & 27.43 & 3.06 & 1.06 & 2.88 & S. predistentus \\
\hline 2 & 27.08 & 2.83 & 1.73 & 1.64 & S. ciperoensis & 3 & 27.43 & 3.34 & 1.16 & 2.87 & S. predistentus \\
\hline 2 & 27.08 & 3.09 & 1.62 & 1.90 & S. ciperoensis & 3 & 27.43 & 3.09 & 1.08 & 2.86 & S. predistentus \\
\hline 2 & 27.08 & 2.38 & 1.57 & 1.52 & S. ciperoensis & 3 & 27.43 & 2.83 & 0.90 & 3.15 & S. predistentus \\
\hline 2 & 27.08 & 2.67 & 1.62 & 1.65 & S. ciperoensis & 3 & 27.43 & 2.33 & 0.79 & 2.96 & S. predistentus \\
\hline 2 & 27.08 & 2.41 & 1.44 & 1.67 & S. ciperoensis & 3 & 27.43 & 2.67 & 1.02 & 2.63 & S. predistentus \\
\hline 2 & 27.08 & 2.33 & 1.60 & 1.46 & S. ciperoensis & 3 & 27.43 & 2.98 & 0.93 & 3.19 & S. predistentus \\
\hline 2 & 27.08 & 2.31 & 1.28 & 1.80 & S. ciperoensis & 3 & 27.43 & 2.78 & 0.87 & 3.21 & S. predistentus \\
\hline 2 & 27.08 & 3.43 & 1.94 & 1.77 & S. ciperoensis & 3 & 27.43 & 2.15 & 0.82 & 2.62 & S. predistentus \\
\hline 2 & 27.08 & 3.12 & 1.62 & 1.92 & S. ciperoensis & 3 & 27.43 & 2.82 & 1.13 & 2.49 & S. predistentus \\
\hline 2 & 27.08 & 2.83 & 1.28 & 2.20 & S. ciperoensis & 3 & 27.43 & 2.87 & 1.06 & 2.69 & S. predistentus \\
\hline 2 & 27.08 & 2.44 & 1.44 & 1.69 & S. ciperoensis & 3 & 27.43 & 3.00 & 0.98 & 3.05 & S. predistentus \\
\hline 2 & 27.08 & 3.41 & 2.49 & 1.37 & S. ciperoensis & 3 & 27.43 & 3.49 & 1.28 & 2.73 & S. predistentus \\
\hline 2 & 27.08 & 2.59 & 1.47 & 1.77 & S. ciperoensis & 3 & 27.43 & 2.88 & 1.16 & 2.48 & S. predistentus \\
\hline 3 & 27.43 & 2.36 & 0.84 & 2.82 & S. predistentus & 3 & 27.43 & 3.18 & 1.03 & 3.08 & S. predistentus \\
\hline 3 & 27.43 & 2.62 & 0.88 & 2.96 & S. predistentus & 3 & 27.43 & 2.37 & 1.03 & 2.30 & S. predistentus \\
\hline 3 & 27.43 & 2.36 & 0.98 & 2.40 & S. predistentus & 3 & 27.43 & 2.44 & 1.02 & 2.40 & S. predistentus \\
\hline 3 & 27.43 & 2.96 & 1.16 & 2.55 & S. predistentus & 3 & 27.43 & 2.72 & 1.21 & 2.24 & S. predistentus \\
\hline 3 & 27.43 & 3.05 & 1.72 & 1.77 & S. predistentus & 3 & 27.43 & 2.90 & 0.93 & 3.11 & S. predistentus \\
\hline 3 & 27.43 & 2.70 & 0.92 & 2.95 & S. predistentus & 3 & 27.43 & 2.64 & 0.87 & 3.04 & S. predistentus \\
\hline 3 & 27.43 & 2.55 & 0.85 & 3.00 & S. predistentus & 3 & 27.43 & 2.88 & 0.97 & 2.98 & S. predistentus \\
\hline 3 & 27.43 & 2.18 & 0.90 & 2.42 & S. predistentus & 3 & 27.43 & 2.54 & 1.02 & 2.50 & S. predistentus \\
\hline 3 & 27.43 & 2.87 & 0.98 & 2.92 & S. predistentus & 3 & 27.43 & 3.18 & 1.13 & 2.81 & S. predistentus \\
\hline 3 & 27.43 & 3.11 & 1.06 & 2.92 & S. predistentus & 3 & 27.43 & 2.67 & 0.98 & 2.72 & S. predistentus \\
\hline 3 & 27.43 & 2.75 & 1.05 & 2.63 & S. predistentus & 3 & 27.43 & 2.11 & 0.74 & 2.87 & S. predistentus \\
\hline 3 & 27.43 & 2.75 & 1.15 & 2.40 & S. predistentus & 3 & 27.43 & 2.46 & 0.95 & 2.59 & S. predistentus \\
\hline 3 & 27.43 & 2.46 & 0.70 & 3.49 & S. predistentus & 3 & 27.43 & 3.29 & 0.95 & 3.47 & S. predistentus \\
\hline 3 & 27.43 & 2.34 & 0.79 & 2.98 & S. predistentus & 3 & 27.43 & 2.85 & 1.46 & 1.96 & S. distentus \\
\hline 3 & 27.43 & 2.36 & 0.85 & 2.77 & S. predistentus & 3 & 27.43 & 2.87 & 1.03 & 2.78 & S. distentus \\
\hline 3 & 27.43 & 2.52 & 0.82 & 3.08 & S. predistentus & 3 & 27.43 & 2.77 & 1.34 & 2.06 & S. distentus \\
\hline 3 & 27.43 & 2.16 & 0.66 & 3.30 & S. predistentus & 3 & 27.43 & 2.77 & 0.98 & 2.82 & S. distentus \\
\hline 3 & 27.43 & 3.31 & 0.95 & 3.48 & S. predistentus & 3 & 27.43 & 3.62 & 1.69 & 2.15 & S. distentus \\
\hline 3 & 27.43 & 2.15 & 0.77 & 2.79 & S. predistentus & 3 & 27.43 & 2.44 & 1.21 & 2.01 & S. distentus \\
\hline 3 & 27.43 & 2.23 & 0.70 & 3.16 & S. predistentus & 3 & 27.43 & 2.72 & 1.60 & 1.69 & S. distentus \\
\hline 3 & 27.43 & 2.06 & 0.77 & 2.68 & S. predistentus & 3 & 27.43 & 2.83 & 1.77 & 1.60 & S. distentus \\
\hline 3 & 27.43 & 2.62 & 0.67 & 3.90 & S. predistentus & 3 & 27.43 & 2.65 & 1.15 & 2.31 & S. distentus \\
\hline 3 & 27.43 & 2.15 & 0.59 & 3.64 & S. predistentus & 3 & 27.43 & 2.34 & 1.29 & 1.81 & S. distentus \\
\hline 3 & 27.43 & 2.49 & 0.69 & 3.62 & S. predistentus & 3 & 27.43 & 2.87 & 1.21 & 2.36 & S. distentus \\
\hline 3 & 27.43 & 2.77 & 1.02 & 2.73 & S. predistentus & 3 & 27.43 & 2.70 & 0.98 & 2.75 & S. distentus \\
\hline 3 & 27.43 & 2.64 & 0.72 & 3.66 & S. predistentus & 3 & 27.43 & 2.42 & 1.02 & 2.39 & S. distentus \\
\hline 3 & 27.43 & 2.39 & 0.87 & 2.75 & S. predistentus & 3 & 27.43 & 3.19 & 1.15 & 2.79 & S. distentus \\
\hline 3 & 27.43 & 2.60 & 0.95 & 2.74 & S. predistentus & 3 & 27.43 & 2.88 & 1.29 & 2.23 & S. distentus \\
\hline 3 & 27.43 & 2.65 & 0.90 & 2.95 & S. predistentus & 3 & 27.43 & 2.65 & 1.26 & 2.10 & S. distentus \\
\hline 3 & 27.43 & 1.93 & 0.67 & 2.88 & S. predistentus & 3 & 27.43 & 2.51 & 1.23 & 2.04 & S. distentus \\
\hline
\end{tabular}

Table A1. Continued.

Table A1. Continued. 
T. Blaj et al.

\begin{tabular}{|c|c|c|c|c|c|}
\hline $\begin{array}{l}\text { Sample } \\
\#\end{array}$ & $\begin{array}{l}\text { Age } \\
\text { (Ma) }\end{array}$ & $\begin{array}{l}\text { Width } \\
(\mu \mathrm{m})\end{array}$ & $\begin{array}{c}\text { Height } \\
(\mu \mathrm{m})\end{array}$ & $\begin{array}{l}\text { Ratio } \\
\text { W/H }\end{array}$ & Species ID \\
\hline 3 & 27.43 & 3.18 & 1.18 & 2.69 & S. distentus \\
\hline 3 & 27.43 & 2.60 & 1.39 & 1.87 & S. distentus \\
\hline 3 & 27.43 & 2.83 & 1.39 & 2.04 & S. distentus \\
\hline 3 & 27.43 & 2.88 & 1.93 & 1.49 & S. distentus \\
\hline 3 & 27.43 & 3.26 & 1.90 & 1.72 & S. distentus \\
\hline 3 & 27.43 & 2.75 & 1.24 & 2.21 & S. distentus \\
\hline 3 & 27.43 & 2.91 & 1.33 & 2.20 & S. distentus \\
\hline 4 & 27.84 & 3.24 & 1.34 & 2.41 & S. predistentus \\
\hline 4 & 27.84 & 2.82 & 1.00 & 2.82 & S. predistentus \\
\hline 4 & 27.84 & 4.73 & 1.67 & 2.83 & S. predistentus \\
\hline 4 & 27.84 & 2.96 & 0.97 & 3.07 & S. predistentus \\
\hline 4 & 27.84 & 3.28 & 1.26 & 2.60 & S. predistentus \\
\hline 4 & 27.84 & 2.87 & 0.97 & 2.97 & S. predistentus \\
\hline 4 & 27.84 & 4.22 & 1.39 & 3.04 & S. predistentus \\
\hline 4 & 27.84 & 2.93 & 0.84 & 3.51 & S. predistentus \\
\hline 4 & 27.84 & 3.67 & 1.28 & 2.87 & S. predistentus \\
\hline 4 & 27.84 & 2.55 & 1.05 & 2.44 & S. predistentus \\
\hline 4 & 27.84 & 4.81 & 1.67 & 2.88 & S. predistentus \\
\hline 4 & 27.84 & 2.26 & 0.84 & 2.71 & S. predistentus \\
\hline 4 & 27.84 & 3.19 & 1.03 & 3.10 & S. predistentus \\
\hline 4 & 27.84 & 2.55 & 0.97 & 2.64 & S. predistentus \\
\hline 4 & 27.84 & 2.87 & 0.90 & 3.18 & S. predistentus \\
\hline 4 & 27.84 & 2.77 & 0.95 & 2.91 & S. predistentus \\
\hline 4 & 27.84 & 2.52 & 0.85 & 2.96 & S. predistentus \\
\hline 4 & 27.84 & 2.83 & 1.06 & 2.66 & S. predistentus \\
\hline 4 & 27.84 & 3.73 & 1.46 & 2.56 & S. predistentus \\
\hline 4 & 27.84 & 2.72 & 0.95 & 2.86 & S. predistentus \\
\hline 4 & 27.84 & 2.47 & 0.92 & 2.70 & S. predistentus \\
\hline 4 & 27.84 & 2.70 & 1.06 & 2.54 & S. predistentus \\
\hline 4 & 27.84 & 3.00 & 1.02 & 2.95 & S. predistentus \\
\hline 4 & 27.84 & 3.72 & 1.44 & 2.58 & S. predistentus \\
\hline 4 & 27.84 & 3.06 & 1.23 & 2.49 & S. predistentus \\
\hline 4 & 27.84 & 2.88 & 1.15 & 2.51 & S. predistentus \\
\hline 4 & 27.84 & 3.09 & 1.34 & 2.30 & S. predistentus \\
\hline 4 & 27.84 & 3.18 & 1.10 & 2.90 & S. predistentus \\
\hline 4 & 27.84 & 2.85 & 1.11 & 2.56 & S. predistentus \\
\hline 4 & 27.84 & 2.75 & 1.06 & 2.58 & S. predistentus \\
\hline 4 & 27.84 & 3.47 & 1.20 & 2.90 & S. predistentus \\
\hline 4 & 27.84 & 2.77 & 1.11 & 2.49 & S. predistentus \\
\hline 4 & 27.84 & 2.59 & 0.98 & 2.63 & S. predistentus \\
\hline 4 & 27.84 & 2.70 & 1.02 & 2.66 & S. predistentus \\
\hline 4 & 27.84 & 2.78 & 0.87 & 3.21 & S. predistentus \\
\hline 4 & 27.84 & 3.08 & 1.10 & 2.81 & S. predistentus \\
\hline 4 & 27.84 & 2.85 & 1.08 & 2.64 & S. predistentus \\
\hline 4 & 27.84 & 3.01 & 1.44 & 2.09 & S. predistentus \\
\hline 4 & 27.84 & 3.18 & 1.08 & 2.94 & S. predistentus \\
\hline 4 & 27.84 & 2.59 & 1.00 & 2.59 & S. predistentus \\
\hline 4 & 27.84 & 2.83 & 1.10 & 2.58 & S. predistentus \\
\hline 4 & 27.84 & 3.26 & 1.51 & 2.16 & S. predistentus \\
\hline 4 & 27.84 & 2.23 & 0.90 & 2.47 & S. predistentus \\
\hline 4 & 27.84 & 2.93 & 0.97 & 3.03 & S. predistentus \\
\hline 4 & 27.84 & 2.88 & 0.92 & 3.14 & S. predistentus \\
\hline 4 & 27.84 & 2.57 & 0.92 & 2.80 & S. predistentus \\
\hline 4 & 27.84 & 2.24 & 0.85 & 2.63 & S. predistentus \\
\hline 4 & 27.84 & 3.13 & 0.98 & 3.18 & S. predistentus \\
\hline 4 & 27.84 & 3.00 & 0.92 & 3.27 & S. predistentus \\
\hline 4 & 27.84 & 2.91 & 1.06 & 2.74 & S. predistentus \\
\hline 4 & 27.84 & 2.64 & 0.95 & 2.78 & S. predistentus \\
\hline 4 & 27.84 & 2.37 & 0.84 & 2.84 & S. predistentus \\
\hline 4 & 27.84 & 2.77 & 0.88 & 3.13 & S. predistentus \\
\hline 4 & 27.84 & 3.26 & 1.10 & 2.97 & S. predistentus \\
\hline 4 & 27.84 & 2.82 & 1.08 & 2.61 & S. predistentus \\
\hline 4 & 27.84 & 2.67 & 0.95 & 2.81 & S. predistentus \\
\hline
\end{tabular}

Table A1. Continued.

\begin{tabular}{|c|c|c|c|c|c|}
\hline $\begin{array}{l}\text { Sample } \\
\text { \# }\end{array}$ & $\begin{array}{l}\text { Age } \\
(\mathrm{Ma})\end{array}$ & $\begin{array}{l}\text { Width } \\
(\mu \mathrm{m})\end{array}$ & $\begin{array}{c}\text { Height } \\
(\mu \mathrm{m})\end{array}$ & $\begin{array}{l}\text { Ratio } \\
\text { W/H }\end{array}$ & Species ID \\
\hline 4 & 27.84 & 2.62 & 0.92 & 2.86 & S. predistentus \\
\hline 4 & 27.84 & 2.33 & 0.92 & 2.54 & S. predistentus \\
\hline 4 & 27.84 & 2.88 & 0.85 & 3.38 & S. predistentus \\
\hline 4 & 27.84 & 2.73 & 0.90 & 3.04 & S. predistentus \\
\hline 4 & 27.84 & 3.95 & 1.38 & 2.87 & S. predistentus \\
\hline 4 & 27.84 & 3.34 & 1.15 & 2.91 & S. predistentus \\
\hline 4 & 27.84 & 2.52 & 1.13 & 2.23 & S. predistentus \\
\hline 4 & 27.84 & 2.91 & 1.39 & 2.09 & S. predistentus \\
\hline 4 & 27.84 & 3.03 & 1.36 & 2.23 & S. distentus \\
\hline 4 & 27.84 & 2.29 & 1.24 & 1.84 & S. distentus \\
\hline 4 & 27.84 & 3.77 & 1.24 & 3.03 & S. distentus \\
\hline 4 & 27.84 & 2.72 & 1.06 & 2.55 & S. distentus \\
\hline 4 & 27.84 & 3.55 & 1.20 & 2.97 & S. distentus \\
\hline 4 & 27.84 & 2.87 & 1.26 & 2.27 & S. distentus \\
\hline 4 & 27.84 & 2.88 & 1.15 & 2.51 & S. distentus \\
\hline 4 & 27.84 & 3.14 & 0.93 & 3.37 & S. distentus \\
\hline 4 & 27.84 & 3.19 & 1.39 & 2.29 & S. distentus \\
\hline 4 & 27.84 & 2.65 & 1.49 & 1.78 & S. distentus \\
\hline 4 & 27.84 & 3.44 & 1.47 & 2.33 & S. distentus \\
\hline 4 & 27.84 & 2.70 & 1.16 & 2.32 & S. distentus \\
\hline 4 & 27.84 & 2.82 & 1.28 & 2.21 & S. distentus \\
\hline 4 & 27.84 & 2.87 & 1.16 & 2.46 & S. distentus \\
\hline 4 & 27.84 & 2.80 & 1.11 & 2.51 & S. distentus \\
\hline 4 & 27.84 & 2.90 & 1.10 & 2.64 & S. distentus \\
\hline 4 & 27.84 & 2.59 & 1.42 & 1.82 & S. distentus \\
\hline 4 & 27.84 & 2.83 & 1.33 & 2.14 & S. distentus \\
\hline 4 & 27.84 & 3.41 & 1.33 & 2.57 & S. distentus \\
\hline 4 & 27.84 & 3.19 & 1.05 & 3.05 & S. distentus \\
\hline 4 & 27.84 & 2.83 & 1.70 & 1.66 & S. distentus \\
\hline 4 & 27.84 & 2.80 & 2.05 & 1.37 & S. distentus \\
\hline 4 & 27.84 & 3.13 & 1.88 & 1.66 & S. distentus \\
\hline 4 & 27.84 & 3.09 & 1.23 & 2.52 & S. distentus \\
\hline 4 & 27.84 & 3.26 & 1.36 & 2.40 & S. distentus \\
\hline 4 & 27.84 & 2.90 & 1.18 & 2.46 & S. distentus \\
\hline 4 & 27.84 & 3.18 & 1.13 & 2.81 & S. distentus \\
\hline 4 & 27.84 & 2.29 & 1.02 & 2.26 & S. distentus \\
\hline 4 & 27.84 & 3.27 & 1.54 & 2.12 & S. distentus \\
\hline 4 & 27.84 & 3.03 & 1.36 & 2.23 & S. distentus \\
\hline 4 & 27.84 & 2.72 & 0.97 & 2.81 & S. distentus \\
\hline 4 & 27.84 & 2.65 & 1.18 & 2.25 & S. distentus \\
\hline 4 & 27.84 & 2.75 & 1.28 & 2.15 & S. distentus \\
\hline 4 & 27.84 & 2.60 & 1.46 & 1.79 & S. distentus \\
\hline 4 & 27.84 & 2.77 & 0.98 & 2.82 & S. distentus \\
\hline 4 & 27.84 & 3.16 & 1.36 & 2.33 & S. distentus \\
\hline 5 & 28.24 & 3.49 & 1.24 & 2.80 & S. predistentus \\
\hline 5 & 28.24 & 2.75 & 1.00 & 2.75 & S. predistentus \\
\hline 5 & 28.24 & 2.67 & 0.87 & 3.08 & S. predistentus \\
\hline 5 & 28.24 & 2.60 & 1.24 & 2.09 & S. predistentus \\
\hline 5 & 28.24 & 3.32 & 0.87 & 3.83 & S. predistentus \\
\hline 5 & 28.24 & 2.75 & 0.93 & 2.95 & S. predistentus \\
\hline 5 & 28.24 & 2.91 & 1.36 & 2.14 & S. predistentus \\
\hline 5 & 28.24 & 3.39 & 1.23 & 2.76 & S. predistentus \\
\hline 5 & 28.24 & 3.32 & 1.21 & 2.74 & S. predistentus \\
\hline 5 & 28.24 & 2.87 & 0.87 & 3.30 & S. predistentus \\
\hline 5 & 28.24 & 2.98 & 1.00 & 2.98 & S. predistentus \\
\hline 5 & 28.24 & 3.18 & 1.15 & 2.77 & S. predistentus \\
\hline 5 & 28.24 & 3.64 & 1.28 & 2.85 & S. predistentus \\
\hline 5 & 28.24 & 2.51 & 0.84 & 3.00 & S. predistentus \\
\hline 5 & 28.24 & 3.52 & 1.39 & 2.53 & S. predistentus \\
\hline 5 & 28.24 & 2.39 & 0.72 & 3.32 & S. predistentus \\
\hline 5 & 28.24 & 2.90 & 0.92 & 3.16 & S. predistentus \\
\hline 5 & 28.24 & 2.72 & 0.97 & 2.81 & S. predistentus \\
\hline 5 & 28.24 & 3.39 & 1.60 & 2.11 & S. predistentus \\
\hline
\end{tabular}

Table A1. Continued. 


\begin{tabular}{|c|c|c|c|c|c|}
\hline $\begin{array}{l}\text { Sample } \\
\text { \# }\end{array}$ & $\begin{array}{l}\text { Age } \\
(\mathrm{Ma})\end{array}$ & $\begin{array}{l}\text { Width } \\
(\mu \mathrm{m})\end{array}$ & $\begin{array}{l}\text { Height } \\
(\mu \mathrm{m})\end{array}$ & $\begin{array}{l}\text { Ratio } \\
\text { W/H }\end{array}$ & Species ID \\
\hline 5 & 28.24 & 2.80 & 1.13 & 2.48 & S. predistentus \\
\hline 5 & 28.24 & 3.68 & 1.21 & 3.04 & S. predistentus \\
\hline 5 & 28.24 & 3.41 & 1.24 & 2.74 & S. predistentus \\
\hline 5 & 28.24 & 2.82 & 1.05 & 2.69 & S. predistentus \\
\hline 5 & 28.24 & 3.06 & 1.34 & 2.28 & S. predistentus \\
\hline 5 & 28.24 & 3.08 & 1.02 & 3.03 & S. predistentus \\
\hline 5 & 28.24 & 3.47 & 1.33 & 2.62 & S. predistentus \\
\hline 5 & 28.24 & 2.47 & 0.92 & 2.70 & S. predistentus \\
\hline 5 & 28.24 & 3.32 & 1.29 & 2.57 & S. predistentus \\
\hline 5 & 28.24 & 3.18 & 1.20 & 2.66 & S. predistentus \\
\hline 5 & 28.24 & 3.23 & 1.31 & 2.46 & S. predistentus \\
\hline 5 & 28.24 & 2.90 & 1.02 & 2.85 & S. predistentus \\
\hline 5 & 28.24 & 3.46 & 1.20 & 2.89 & S. predistentus \\
\hline 5 & 28.24 & 2.44 & 1.02 & 2.40 & S. predistentus \\
\hline 5 & 28.24 & 2.65 & 0.85 & 3.12 & S. predistentus \\
\hline 5 & 28.24 & 2.85 & 1.05 & 2.72 & S. predistentus \\
\hline 5 & 28.24 & 2.15 & 0.90 & 2.38 & S. predistentus \\
\hline 5 & 28.24 & 3.64 & 1.42 & 2.55 & S. predistentus \\
\hline 5 & 28.24 & 2.78 & 0.85 & 3.27 & S. predistentus \\
\hline 5 & 28.24 & 3.09 & 1.26 & 2.45 & S. predistentus \\
\hline 5 & 28.24 & 3.24 & 1.05 & 3.09 & S. predistentus \\
\hline 5 & 28.24 & 2.65 & 1.20 & 2.22 & S. predistentus \\
\hline 5 & 28.24 & 3.14 & 1.62 & 1.94 & S. predistentus \\
\hline 5 & 28.24 & 3.14 & 1.26 & 2.49 & S. predistentus \\
\hline 5 & 28.24 & 2.85 & 1.10 & 2.60 & S. predistentus \\
\hline 5 & 28.24 & 3.00 & 1.00 & 3.00 & S. predistentus \\
\hline 5 & 28.24 & 3.09 & 1.31 & 2.36 & S. predistentus \\
\hline 5 & 28.24 & 3.59 & 1.11 & 3.22 & S. predistentus \\
\hline 5 & 28.24 & 3.36 & 1.34 & 2.50 & S. predistentus \\
\hline 5 & 28.24 & 2.91 & 1.02 & 2.87 & S. predistentus \\
\hline 5 & 28.24 & 2.85 & 1.15 & 2.49 & S. predistentus \\
\hline 5 & 28.24 & 3.34 & 1.41 & 2.37 & S. predistentus \\
\hline 5 & 28.24 & 2.77 & 1.26 & 2.19 & S. predistentus \\
\hline 5 & 28.24 & 2.51 & 1.05 & 2.39 & S. predistentus \\
\hline 5 & 28.24 & 3.18 & 1.21 & 2.63 & S. predistentus \\
\hline 5 & 28.24 & 3.42 & 1.57 & 2.18 & S. predistentus \\
\hline 5 & 28.24 & 2.21 & 0.84 & 2.65 & S. predistentus \\
\hline 5 & 28.24 & 3.47 & 1.29 & 2.68 & S. predistentus \\
\hline 5 & 28.24 & 2.44 & 1.03 & 2.37 & S. predistentus \\
\hline 5 & 28.24 & 2.54 & 1.15 & 2.21 & S. predistentus \\
\hline 5 & 28.24 & 3.13 & 1.08 & 2.89 & S. predistentus \\
\hline 5 & 28.24 & 3.29 & 0.98 & 3.35 & S. predistentus \\
\hline 5 & 28.24 & 2.62 & 1.41 & 1.86 & S. predistentus \\
\hline 5 & 28.24 & 3.05 & 1.16 & 2.62 & S. predistentus \\
\hline 5 & 28.24 & 2.57 & 1.18 & 2.18 & S. predistentus \\
\hline 5 & 28.24 & 2.85 & 0.77 & 3.70 & S. predistentus \\
\hline 5 & 28.24 & 3.28 & 1.18 & 2.78 & S. predistentus \\
\hline 5 & 28.24 & 2.96 & 1.10 & 2.70 & S. predistentus \\
\hline 5 & 28.24 & 3.18 & 1.31 & 2.43 & S. predistentus \\
\hline 5 & 28.24 & 3.09 & 1.23 & 2.52 & S. predistentus \\
\hline 5 & 28.24 & 3.31 & 1.08 & 3.06 & S. predistentus \\
\hline 5 & 28.24 & 4.21 & 1.95 & 2.16 & S. distentus \\
\hline 5 & 28.24 & 3.01 & 1.24 & 2.42 & S. distentus \\
\hline 5 & 28.24 & 4.22 & 1.75 & 2.41 & S. distentus \\
\hline 5 & 28.24 & 2.85 & 1.13 & 2.52 & S. distentus \\
\hline 5 & 28.24 & 3.39 & 1.56 & 2.18 & S. distentus \\
\hline 5 & 28.24 & 3.36 & 1.29 & 2.59 & S. distentus \\
\hline 5 & 28.24 & 3.13 & 1.13 & 2.77 & S. distentus \\
\hline 5 & 28.24 & 3.36 & 1.47 & 2.28 & S. distentus \\
\hline 5 & 28.24 & 3.11 & 1.44 & 2.16 & S. distentus \\
\hline 5 & 28.24 & 3.42 & 1.41 & 2.43 & S. distentus \\
\hline 5 & 28.24 & 2.91 & 1.28 & 2.28 & S. distentus \\
\hline 5 & 28.24 & 3.55 & 1.83 & 1.94 & S. distentus \\
\hline
\end{tabular}

Table A1. Continued.

\begin{tabular}{|c|c|c|c|c|c|}
\hline $\begin{array}{l}\text { Sample } \\
\text { \# }\end{array}$ & $\begin{array}{l}\text { Age } \\
\text { (Ma) }\end{array}$ & $\begin{array}{c}\text { Width } \\
(\mu \mathrm{m})\end{array}$ & $\begin{array}{l}\text { Height } \\
(\mu \mathrm{m})\end{array}$ & $\begin{array}{c}\text { Ratio } \\
\text { W/H }\end{array}$ & Species ID \\
\hline 5 & 28.24 & 3.62 & 1.62 & 2.23 & S. distentus \\
\hline 5 & 28.24 & 3.13 & 1.15 & 2.73 & S. distentus \\
\hline 5 & 28.24 & 2.23 & 1.00 & 2.23 & S. distentus \\
\hline 5 & 28.24 & 3.19 & 1.64 & 1.95 & S. distentus \\
\hline 5 & 28.24 & 3.08 & 1.41 & 2.19 & S. distentus \\
\hline 5 & 28.24 & 3.06 & 1.24 & 2.46 & S. distentus \\
\hline 5 & 28.24 & 2.75 & 1.70 & 1.62 & S. distentus \\
\hline 5 & 28.24 & 2.37 & 0.97 & 2.46 & S. distentus \\
\hline 5 & 28.24 & 3.44 & 1.90 & 1.81 & S. distentus \\
\hline 5 & 28.24 & 2.28 & 1.08 & 2.11 & S. distentus \\
\hline 5 & 28.24 & 2.87 & 1.08 & 2.65 & S. distentus \\
\hline 5 & 28.24 & 2.85 & 1.70 & 1.67 & S. distentus \\
\hline 5 & 28.24 & 2.62 & 1.38 & 1.90 & S. distentus \\
\hline 5 & 28.24 & 2.87 & 1.82 & 1.58 & S. distentus \\
\hline 5 & 28.24 & 3.72 & 1.60 & 2.33 & S. distentus \\
\hline 5 & 28.24 & 2.77 & 1.03 & 2.68 & S. distentus \\
\hline 5 & 28.24 & 2.65 & 1.28 & 2.08 & S. distentus \\
\hline 5 & 28.24 & 2.88 & 1.26 & 2.29 & S. distentus \\
\hline 6 & 28.54 & 2.85 & 0.93 & 3.05 & S. predistentus \\
\hline 6 & 28.54 & 2.59 & 0.85 & 3.04 & S. predistentus \\
\hline 6 & 28.54 & 3.11 & 1.15 & 2.71 & S. predistentus \\
\hline 6 & 28.54 & 3.59 & 1.34 & 2.67 & S. predistentus \\
\hline 6 & 28.54 & 2.39 & 0.87 & 2.75 & S. predistentus \\
\hline 6 & 28.54 & 2.80 & 1.05 & 2.67 & S. predistentus \\
\hline 6 & 28.54 & 3.01 & 1.03 & 2.92 & S. predistentus \\
\hline 6 & 28.54 & 3.08 & 1.31 & 2.35 & S. predistentus \\
\hline 6 & 28.54 & 3.82 & 1.41 & 2.71 & S. predistentus \\
\hline 6 & 28.54 & 2.72 & 1.11 & 2.44 & S. predistentus \\
\hline 6 & 28.54 & 3.36 & 1.26 & 2.66 & S. predistentus \\
\hline 6 & 28.54 & 2.93 & 1.02 & 2.89 & S. predistentus \\
\hline 6 & 28.54 & 2.70 & 0.98 & 2.75 & S. predistentus \\
\hline 6 & 28.54 & 3.54 & 1.11 & 3.18 & S. predistentus \\
\hline 6 & 28.54 & 2.83 & 1.02 & 2.79 & S. predistentus \\
\hline 6 & 28.54 & 2.98 & 1.03 & 2.89 & S. predistentus \\
\hline 6 & 28.54 & 3.52 & 0.97 & 3.64 & S. predistentu. \\
\hline 6 & 28.54 & 3.37 & 0.98 & 3.43 & S. predistentus \\
\hline 6 & 28.54 & 3.24 & 1.00 & 3.25 & S. predistentus \\
\hline 6 & 28.54 & 2.88 & 0.92 & 3.14 & S. predistentus \\
\hline 6 & 28.54 & 3.62 & 1.18 & 3.07 & S. predistentus \\
\hline 6 & 28.54 & 3.03 & 1.11 & 2.72 & S. predistentus \\
\hline 6 & 28.54 & 2.69 & 1.20 & 2.25 & S. predistentus \\
\hline 6 & 28.54 & 3.24 & 1.10 & 2.96 & S. predistentu. \\
\hline 6 & 28.54 & 3.21 & 1.46 & 2.20 & S. predistentus \\
\hline 6 & 28.54 & 2.91 & 1.11 & 2.62 & S. predistentus \\
\hline 6 & 28.54 & 2.87 & 0.80 & 3.57 & S. predistentus \\
\hline 6 & 28.54 & 2.65 & 0.84 & 3.18 & S. predistentus \\
\hline 6 & 28.54 & 2.85 & 1.08 & 2.64 & S. predistentus \\
\hline 6 & 28.54 & 3.14 & 1.28 & 2.46 & S. predistentus \\
\hline 6 & 28.54 & 2.67 & 0.82 & 3.26 & S. predistentus \\
\hline 6 & 28.54 & 3.06 & 1.23 & 2.49 & S. predistentus \\
\hline 6 & 28.54 & 2.80 & 1.10 & 2.55 & S. predistentus \\
\hline 6 & 28.54 & 2.60 & 0.87 & 3.00 & S. predistentus \\
\hline 6 & 28.54 & 3.01 & 1.42 & 2.11 & S. predistentus \\
\hline 6 & 28.54 & 2.64 & 1.08 & 2.44 & S. predistentus \\
\hline 6 & 28.54 & 3.18 & 1.77 & 1.80 & S. predistentus \\
\hline 6 & 28.54 & 2.85 & 1.08 & 2.64 & S. predistentus \\
\hline 6 & 28.54 & 2.49 & 1.03 & 2.41 & S. predistentus \\
\hline 6 & 28.54 & 2.93 & 1.20 & 2.45 & S. predistentus \\
\hline 6 & 28.54 & 2.75 & 1.06 & 2.58 & S. predistentus \\
\hline 6 & 28.54 & 2.98 & 1.21 & 2.46 & S. predistentus \\
\hline 6 & 28.54 & 2.67 & 1.25 & 2.12 & S. predistentus \\
\hline 6 & 28.54 & 2.82 & 0.98 & 2.87 & S. predistentus \\
\hline 6 & 28.54 & 2.88 & 1.10 & 2.63 & S. predistentus \\
\hline
\end{tabular}

Table A1. Continued. 
T. Blaj et al.

\begin{tabular}{|c|c|c|c|c|c|}
\hline $\begin{array}{l}\text { Sample } \\
\#\end{array}$ & $\begin{array}{l}\text { Age } \\
\text { (Ma) }\end{array}$ & $\begin{array}{l}\text { Width } \\
(\mu \mathrm{m})\end{array}$ & $\begin{array}{l}\text { Height } \\
(\mu \mathrm{m})\end{array}$ & $\begin{array}{l}\text { Ratio } \\
\text { W/H }\end{array}$ & Species ID \\
\hline 6 & 28.54 & 2.90 & 0.93 & 3.11 & S. predistentus \\
\hline 6 & 28.54 & 2.95 & 1.02 & 2.90 & S. predistentus \\
\hline 6 & 28.54 & 2.44 & 0.87 & 2.81 & S. predistentus \\
\hline 6 & 28.54 & 2.69 & 0.70 & 3.81 & S. predistentus \\
\hline 6 & 28.54 & 2.83 & 1.03 & 2.75 & S. predistentus \\
\hline 6 & 28.54 & 2.95 & 1.36 & 2.17 & S. predistentus \\
\hline 6 & 28.54 & 3.06 & 1.15 & 2.67 & S. predistentus \\
\hline 6 & 28.54 & 3.05 & 1.18 & 2.58 & S. predistentus \\
\hline 6 & 28.54 & 3.39 & 1.34 & 2.52 & S. predistentus \\
\hline 6 & 28.54 & 3.16 & 1.20 & 2.64 & S. predistentus \\
\hline 6 & 28.54 & 2.78 & 0.93 & 2.98 & S. predistentus \\
\hline 6 & 28.54 & 3.19 & 1.18 & 2.71 & S. predistentus \\
\hline 6 & 28.54 & 3.90 & 1.62 & 2.40 & S. predistentus \\
\hline 6 & 28.54 & 3.18 & 1.34 & 2.37 & S. predistentus \\
\hline 6 & 28.54 & 3.09 & 1.10 & 2.82 & S. predistentus \\
\hline 6 & 28.54 & 3.31 & 1.34 & 2.46 & S. predistentus \\
\hline 6 & 28.54 & 3.80 & 1.46 & 2.61 & S. predistentus \\
\hline 6 & 28.54 & 3.03 & 1.20 & 2.53 & S. predistentus \\
\hline 6 & 28.54 & 3.13 & 0.87 & 3.60 & S. predistentus \\
\hline 6 & 28.54 & 2.54 & 0.87 & 2.92 & S. predistentus \\
\hline 6 & 28.54 & 3.16 & 1.13 & 2.80 & S. predistentus \\
\hline 6 & 28.54 & 2.41 & 1.00 & 2.41 & S. predistentus \\
\hline 6 & 28.54 & 3.09 & 0.82 & 3.78 & S. predistentus \\
\hline 6 & 28.54 & 3.31 & 1.15 & 2.89 & S. predistentus \\
\hline 6 & 28.54 & 2.85 & 1.03 & 2.76 & S. predistentus \\
\hline 6 & 28.54 & 2.75 & 0.98 & 2.80 & S. predistentus \\
\hline 6 & 28.54 & 3.23 & 1.51 & 2.14 & S. distentus \\
\hline 6 & 28.54 & 3.31 & 1.34 & 2.46 & S. distentus \\
\hline 6 & 28.54 & 2.93 & 1.24 & 2.36 & S. distentus \\
\hline 6 & 28.54 & 2.75 & 1.13 & 2.43 & S. distentus \\
\hline 6 & 28.54 & 2.90 & 1.10 & 2.64 & S. distentus \\
\hline 6 & 28.54 & 3.14 & 1.31 & 2.40 & S. distentus \\
\hline 6 & 28.54 & 2.88 & 1.57 & 1.83 & S. distentus \\
\hline 6 & 28.54 & 3.34 & 1.70 & 1.96 & S. distentus \\
\hline 6 & 28.54 & 3.49 & 1.47 & 2.37 & S. distentus \\
\hline 6 & 28.54 & 4.13 & 2.00 & 2.07 & S. distentus \\
\hline 6 & 28.54 & 4.00 & 1.92 & 2.09 & S. distentus \\
\hline 6 & 28.54 & 3.24 & 1.65 & 1.96 & S. distentus \\
\hline 6 & 28.54 & 3.70 & 2.01 & 1.84 & S. distentus \\
\hline 6 & 28.54 & 3.00 & 1.38 & 2.18 & S. distentus \\
\hline 6 & 28.54 & 3.44 & 1.34 & 2.56 & S. distentus \\
\hline 6 & 28.54 & 3.37 & 1.60 & 2.10 & S. distentus \\
\hline 6 & 28.54 & 3.65 & 1.52 & 2.40 & S. distentus \\
\hline 6 & 28.54 & 3.50 & 1.49 & 2.35 & S. distentus \\
\hline 6 & 28.54 & 3.23 & 1.39 & 2.32 & S. distentus \\
\hline 6 & 28.54 & 2.78 & 1.47 & 1.89 & S. distentus \\
\hline 6 & 28.54 & 3.47 & 1.39 & 2.49 & S. distentus \\
\hline 6 & 28.54 & 3.06 & 1.41 & 2.17 & S. distentus \\
\hline 6 & 28.54 & 3.44 & 1.41 & 2.44 & S. distentus \\
\hline 6 & 28.54 & 2.82 & 1.15 & 2.46 & S. distentus \\
\hline 6 & 28.54 & 4.03 & 1.92 & 2.10 & S. distentus \\
\hline 6 & 28.54 & 2.96 & 1.34 & 2.21 & S. distentus \\
\hline 6 & 28.54 & 2.95 & 1.16 & 2.54 & S. distentus \\
\hline 6 & 28.54 & 3.14 & 1.51 & 2.09 & S. distentus \\
\hline 6 & 28.54 & 2.93 & 1.44 & 2.03 & S. distentus \\
\hline 7 & 28.89 & 3.08 & 0.95 & 3.24 & S. predistentus \\
\hline 7 & 28.89 & 3.75 & 1.18 & 3.18 & S. predistentus \\
\hline 7 & 28.89 & 2.37 & 0.82 & 2.90 & S. predistentus \\
\hline 7 & 28.89 & 3.03 & 1.18 & 2.57 & S. predistentus \\
\hline 7 & 28.89 & 2.31 & 0.74 & 3.13 & S. predistentus \\
\hline 7 & 28.89 & 3.52 & 1.39 & 2.53 & S. predistentus \\
\hline 7 & 28.89 & 3.32 & 1.10 & 3.03 & S. predistentus \\
\hline 7 & 28.89 & 2.83 & 1.29 & 2.19 & S. predistentus \\
\hline
\end{tabular}

Table A1. Continued.

\begin{tabular}{|c|c|c|c|c|c|}
\hline $\begin{array}{l}\text { Sample } \\
\text { \# }\end{array}$ & $\begin{array}{l}\text { Age } \\
(\mathrm{Ma})\end{array}$ & $\begin{array}{l}\text { Width } \\
(\mu \mathrm{m})\end{array}$ & $\begin{array}{c}\text { Height } \\
(\mu \mathrm{m})\end{array}$ & $\begin{array}{l}\text { Ratio } \\
\text { W/H }\end{array}$ & Species ID \\
\hline 7 & 28.89 & 2.70 & 0.98 & 2.75 & S. predistentus \\
\hline 7 & 28.89 & 3.16 & 1.13 & 2.80 & S. predistentus \\
\hline 7 & 28.89 & 3.27 & 1.28 & 2.56 & S. predistentus \\
\hline 7 & 28.89 & 2.88 & 0.93 & 3.09 & S. predistentus \\
\hline 7 & 28.89 & 3.32 & 1.21 & 2.74 & S. predistentus \\
\hline 7 & 28.89 & 2.60 & 0.83 & 3.12 & S. predistentus \\
\hline 7 & 28.89 & 3.44 & 1.08 & 3.18 & S. predistentus \\
\hline 7 & 28.89 & 3.08 & 1.10 & 2.81 & S. predistentus \\
\hline 7 & 28.89 & 4.16 & 1.87 & 2.23 & S. predistentus \\
\hline 7 & 28.89 & 2.45 & 0.79 & 3.12 & S. predistentus \\
\hline 7 & 28.89 & 3.11 & 0.92 & 3.39 & S. predistentus \\
\hline 7 & 28.89 & 3.11 & 1.33 & 2.35 & S. predistentus \\
\hline 7 & 28.89 & 2.78 & 0.92 & 3.04 & S. predistentus \\
\hline 7 & 28.89 & 3.22 & 1.16 & 2.77 & S. predistentus \\
\hline 7 & 28.89 & 3.70 & 1.36 & 2.72 & S. predistentus \\
\hline 7 & 28.89 & 3.58 & 1.46 & 2.46 & S. predistentus \\
\hline 7 & 28.89 & 3.08 & 1.03 & 2.98 & S. predistentus \\
\hline 7 & 28.89 & 3.40 & 1.31 & 2.60 & S. predistentus \\
\hline 7 & 28.89 & 2.88 & 1.06 & 2.71 & S. predistentus \\
\hline 7 & 28.89 & 2.93 & 1.01 & 2.89 & S. predistentus \\
\hline 7 & 28.89 & 3.32 & 1.26 & 2.64 & S. predistentus \\
\hline 7 & 28.89 & 3.35 & 1.03 & 3.25 & S. predistentus \\
\hline 7 & 28.89 & 2.63 & 1.06 & 2.48 & S. predistentus \\
\hline 7 & 28.89 & 3.34 & 1.41 & 2.37 & S. predistentus \\
\hline 7 & 28.89 & 2.88 & 1.13 & 2.55 & S. predistentus \\
\hline 7 & 28.89 & 3.65 & 1.42 & 2.56 & S. predistentus \\
\hline 7 & 28.89 & 3.45 & 1.47 & 2.34 & S. predistentus \\
\hline 7 & 28.89 & 2.95 & 1.03 & 2.86 & S. predistentus \\
\hline 7 & 28.89 & 2.32 & 0.64 & 3.64 & S. predistentus \\
\hline 7 & 28.89 & 3.04 & 1.10 & 2.78 & S. predistentus \\
\hline 7 & 28.89 & 2.83 & 0.93 & 3.04 & S. predistentus \\
\hline 7 & 28.89 & 2.63 & 0.97 & 2.73 & S. predistentus \\
\hline 7 & 28.89 & 3.11 & 1.23 & 2.53 & S. predistentus \\
\hline 7 & 28.89 & 3.11 & 1.03 & 3.02 & S. predistentus \\
\hline 7 & 28.89 & 2.73 & 1.08 & 2.53 & S. predistentus \\
\hline 7 & 28.89 & 3.70 & 1.39 & 2.66 & S. predistentus \\
\hline 7 & 28.89 & 2.59 & 0.95 & 2.72 & S. predistentus \\
\hline 7 & 28.89 & 2.72 & 0.93 & 2.91 & S. predistentus \\
\hline 7 & 28.89 & 3.14 & 1.36 & 2.31 & S. predistentus \\
\hline 7 & 28.89 & 3.40 & 1.11 & 3.06 & S. predistentus \\
\hline 7 & 28.89 & 2.42 & 1.08 & 2.24 & S. predistentus \\
\hline 7 & 28.89 & 3.03 & 1.10 & 2.76 & S. predistentus \\
\hline 7 & 28.89 & 2.78 & 0.92 & 3.04 & S. predistentus \\
\hline 7 & 28.89 & 2.68 & 1.21 & 2.22 & S. predistentus \\
\hline 7 & 28.89 & 2.59 & 1.11 & 2.32 & S. predistentus \\
\hline 7 & 28.89 & 2.83 & 1.18 & 2.40 & S. predistentus \\
\hline 7 & 28.89 & 2.91 & 0.97 & 3.02 & S. predistentus \\
\hline 7 & 28.89 & 2.63 & 0.83 & 3.16 & S. predistentus \\
\hline 7 & 28.89 & 2.24 & 0.88 & 2.54 & S. predistentus \\
\hline 7 & 28.89 & 2.83 & 1.23 & 2.31 & S. predistentus \\
\hline 7 & 28.89 & 3.06 & 1.06 & 2.88 & S. predistentus \\
\hline 7 & 28.89 & 3.62 & 1.55 & 2.33 & S. predistentus \\
\hline 7 & 28.89 & 2.99 & 0.83 & 3.59 & S. predistentus \\
\hline 7 & 28.89 & 3.35 & 1.44 & 2.33 & S. predistentus \\
\hline 7 & 28.89 & 2.65 & 1.31 & 2.02 & S. predistentus \\
\hline 7 & 28.89 & 3.13 & 1.10 & 2.85 & S. predistentus \\
\hline 7 & 28.89 & 3.45 & 1.21 & 2.85 & S. predistentus \\
\hline 7 & 28.89 & 2.83 & 0.88 & 3.20 & S. predistentus \\
\hline 7 & 28.89 & 2.75 & 1.28 & 2.15 & S. predistentus \\
\hline 7 & 28.89 & 3.48 & 1.15 & 3.04 & S. predistentus \\
\hline 7 & 28.89 & 2.91 & 1.06 & 2.74 & S. predistentus \\
\hline 7 & 28.89 & 2.83 & 1.00 & 2.84 & S. predistentus \\
\hline 7 & 28.89 & 2.91 & 1.55 & 1.87 & S. predistentus \\
\hline
\end{tabular}

Table A1. Continued. 


\begin{tabular}{|c|c|c|c|c|c|c|c|c|c|c|c|}
\hline $\begin{array}{l}\text { Sample } \\
\#\end{array}$ & $\begin{array}{l}\text { Age } \\
\text { (Ma) }\end{array}$ & $\begin{array}{l}\text { Width } \\
(\mu \mathrm{m})\end{array}$ & $\begin{array}{l}\text { Height } \\
(\mu \mathrm{m})\end{array}$ & $\begin{array}{l}\text { Ratio } \\
\text { W/H }\end{array}$ & Species ID & $\begin{array}{l}\text { Sample } \\
\#\end{array}$ & $\begin{array}{l}\text { Age } \\
(\mathrm{Ma})\end{array}$ & $\begin{array}{l}\text { Width } \\
(\mu \mathrm{m})\end{array}$ & $\begin{array}{l}\text { Height } \\
(\mu \mathrm{m})\end{array}$ & $\begin{array}{l}\text { Ratio } \\
\text { W/H }\end{array}$ & Species ID \\
\hline 7 & 28.89 & 2.99 & 1.11 & 2.69 & S. predistentus & 8 & 29.20 & 2.87 & 1.05 & 2.73 & S. predistentus \\
\hline 7 & 28.89 & 2.95 & 1.10 & 2.69 & S. predistentus & 8 & 29.20 & 3.72 & 1.52 & 2.44 & S. predistentus \\
\hline 7 & 28.89 & 3.48 & 1.31 & 2.66 & S. distentus & 8 & 29.20 & 2.83 & 0.97 & 2.93 & S. predistentus \\
\hline 7 & 28.89 & 3.81 & 1.47 & 2.59 & S. distentus & 8 & 29.20 & 2.34 & 0.88 & 2.65 & S. predistentus \\
\hline 7 & 28.89 & 2.99 & 1.49 & 2.01 & S. distentus & 8 & 29.20 & 3.19 & 1.39 & 2.29 & S. predistentus \\
\hline 7 & 28.89 & 2.85 & 2.00 & 1.43 & S. distentus & 8 & 29.20 & 3.08 & 0.92 & 3.36 & S. predistentus \\
\hline 7 & 28.89 & 2.80 & 1.26 & 2.22 & S. distentus & 8 & 29.20 & 3.05 & 1.20 & 2.55 & S. predistentus \\
\hline 7 & 28.89 & 2.80 & 1.18 & 2.37 & S. distentus & 8 & 29.20 & 3.36 & 0.98 & 3.42 & S. predistentus \\
\hline 7 & 28.89 & 2.80 & 1.31 & 2.14 & S. distentus & 8 & 29.20 & 3.01 & 1.26 & 2.39 & S. predistentus \\
\hline 7 & 28.89 & 3.22 & 1.34 & 2.40 & S. distentus & 8 & 29.20 & 3.50 & 0.93 & 3.75 & S. predistentus \\
\hline 7 & 28.89 & 2.67 & 0.98 & 2.72 & S. distentus & 8 & 29.20 & 3.60 & 1.38 & 2.62 & S. predistentus \\
\hline 7 & 28.89 & 3.03 & 1.28 & 2.37 & S. distentus & 8 & 29.20 & 2.83 & 0.85 & 3.33 & S. predistentus \\
\hline 7 & 28.89 & 2.49 & 1.06 & 2.34 & S. distentus & 8 & 29.20 & 3.42 & 1.64 & 2.09 & S. predistentus \\
\hline 7 & 28.89 & 2.14 & 0.75 & 2.85 & S. distentus & 8 & 29.20 & 2.62 & 0.84 & 3.14 & S. predistentus \\
\hline 7 & 28.89 & 2.47 & 1.28 & 1.94 & S. distentus & 8 & 29.20 & 4.50 & 1.42 & 3.16 & S. predistentus \\
\hline 7 & 28.89 & 2.39 & 1.15 & 2.09 & S. distentus & 8 & 29.20 & 3.50 & 1.03 & 3.40 & S. predistentus \\
\hline 7 & 28.89 & 3.65 & 2.00 & 1.83 & S. distentus & 8 & 29.20 & 2.91 & 1.10 & 2.66 & S. predistentus \\
\hline 7 & 28.89 & 2.52 & 1.11 & 2.26 & S. distentus & 8 & 29.20 & 4.54 & 1.97 & 2.31 & S. predistentus \\
\hline 7 & 28.89 & 2.67 & 1.06 & 2.51 & S. distentus & 8 & 29.20 & 3.95 & 1.56 & 2.54 & S. predistentus \\
\hline 7 & 28.89 & 3.04 & 1.78 & 1.71 & S. distentus & 8 & 29.20 & 3.65 & 1.46 & 2.51 & S. predistentus \\
\hline 7 & 28.89 & 3.24 & 1.42 & 2.28 & S. distentus & 8 & 29.20 & 3.03 & 1.23 & 2.47 & S. predistentus \\
\hline 7 & 28.89 & 2.62 & 1.10 & 2.39 & S. distentus & 8 & 29.20 & 3.16 & 1.39 & 2.27 & S. predistentus \\
\hline 7 & 28.89 & 3.14 & 1.26 & 2.49 & S. distentus & 8 & 29.20 & 3.00 & 0.85 & 3.52 & S. predistentus \\
\hline 7 & 28.89 & 2.65 & 1.23 & 2.16 & S. distentus & 8 & 29.20 & 3.47 & 1.47 & 2.36 & S. distentus \\
\hline 7 & 28.89 & 3.24 & 1.16 & 2.79 & S. distentus & 8 & 29.20 & 2.83 & 1.16 & 2.44 & S. distentus \\
\hline 7 & 28.89 & 3.17 & 1.59 & 2.00 & S. distentus & 8 & 29.20 & 3.28 & 1.36 & 2.41 & S. distentus \\
\hline 7 & 28.89 & 3.34 & 1.93 & 1.73 & S. distentus & 8 & 29.20 & 2.64 & 1.64 & 1.61 & S. distentus \\
\hline 7 & 28.89 & 3.34 & 1.34 & 2.49 & S. distentus & 8 & 29.20 & 3.37 & 1.65 & 2.04 & S. distentus \\
\hline 7 & 28.89 & 3.55 & 1.51 & 2.36 & S. distentus & 8 & 29.20 & 2.47 & 1.11 & 2.22 & S. distentus \\
\hline 8 & 29.20 & 2.55 & 0.95 & 2.69 & S. predistentus & 8 & 29.20 & 2.80 & 1.28 & 2.19 & S. distentus \\
\hline 8 & 29.20 & 4.13 & 1.54 & 2.68 & S. predistentus & 8 & 29.20 & 3.70 & 1.72 & 2.15 & S. distentus \\
\hline 8 & 29.20 & 3.19 & 1.47 & 2.17 & S. predistentus & 8 & 29.20 & 3.32 & 1.31 & 2.54 & S. distentus \\
\hline 8 & 29.20 & 4.13 & 1.75 & 2.36 & S. predistentus & 8 & 29.20 & 2.95 & 1.10 & 2.69 & S. distentus \\
\hline 8 & 29.20 & 4.19 & 1.38 & 3.05 & S. predistentus & 8 & 29.20 & 2.88 & 1.56 & 1.85 & S. distentus \\
\hline 8 & 29.20 & 3.19 & 1.36 & 2.35 & S. predistentus & 8 & 29.20 & 3.34 & 1.42 & 2.34 & S. distentus \\
\hline 8 & 29.20 & 2.91 & 1.23 & 2.37 & S. predistentus & 8 & 29.20 & 3.00 & 1.36 & 2.20 & S. distentus \\
\hline 8 & 29.20 & 4.11 & 1.90 & 2.16 & S. predistentus & 8 & 29.20 & 3.47 & 1.38 & 2.52 & S. distentus \\
\hline 8 & 29.20 & 3.75 & 1.15 & 3.27 & S. predistentus & 8 & 29.20 & 2.96 & 1.29 & 2.29 & S. distentus \\
\hline 8 & 29.20 & 3.03 & 1.21 & 2.50 & S. predistentus & 8 & 29.20 & 3.21 & 1.67 & 1.92 & S. distentus \\
\hline 8 & 29.20 & 2.85 & 0.52 & 5.44 & S. predistentus & 8 & 29.20 & 2.55 & 1.13 & 2.26 & S. distentus \\
\hline 8 & 29.20 & 2.54 & 0.92 & 2.77 & S. predistentus & 8 & 29.20 & 2.96 & 1.10 & 2.70 & S. distentus \\
\hline 8 & 29.20 & 2.77 & 0.85 & 3.25 & S. predistentus & 8 & 29.20 & 3.23 & 1.83 & 1.76 & S. distentus \\
\hline 8 & 29.20 & 3.13 & 1.39 & 2.25 & S. predistentus & 8 & 29.20 & 3.42 & 1.92 & 1.79 & S. distentus \\
\hline 8 & 29.20 & 3.18 & 1.23 & 2.59 & S. predistentus & 8 & 29.20 & 2.65 & 1.18 & 2.25 & S. distentus \\
\hline 8 & 29.20 & 2.60 & 0.87 & 3.00 & S. predistentus & 8 & 29.20 & 3.41 & 1.88 & 1.81 & S. distentus \\
\hline 8 & 29.20 & 2.95 & 0.97 & 3.05 & S. predistentus & 8 & 29.20 & 3.21 & 0.98 & 3.27 & S. distentus \\
\hline 8 & 29.20 & 2.65 & 0.97 & 2.75 & S. predistentus & 8 & 29.20 & 2.98 & 1.24 & 2.39 & S. distentus \\
\hline 8 & 29.20 & 4.04 & 1.34 & 3.01 & S. predistentus & 8 & 29.20 & 3.52 & 1.97 & 1.79 & S. distentus \\
\hline 8 & 29.20 & 2.78 & 1.31 & 2.13 & S. predistentus & 8 & 29.20 & 3.82 & 2.21 & 1.73 & S. distentus \\
\hline 8 & 29.20 & 2.62 & 0.88 & 2.96 & S. predistentus & 8 & 29.20 & 2.67 & 1.34 & 1.99 & S. distentus \\
\hline 8 & 29.20 & 3.18 & 1.16 & 2.73 & S. predistentus & 8 & 29.20 & 3.54 & 1.85 & 1.91 & S. distentus \\
\hline 8 & 29.20 & 3.36 & 1.21 & 2.77 & S. predistentus & 8 & 29.20 & 3.64 & 1.24 & 2.92 & S. distentus \\
\hline 8 & 29.20 & 3.88 & 1.52 & 2.55 & S. predistentus & 8 & 29.20 & 3.41 & 1.72 & 1.98 & S. distentus \\
\hline 8 & 29.20 & 4.03 & 1.41 & 2.86 & S. predistentus & 8 & 29.20 & 2.70 & 1.10 & 2.46 & S. distentus \\
\hline 8 & 29.20 & 3.55 & 1.33 & 2.68 & S. predistentus & 8 & 29.20 & 3.59 & 2.01 & 1.78 & S. distentus \\
\hline 8 & 29.20 & 3.31 & 1.44 & 2.30 & S. predistentus & 8 & 29.20 & 3.57 & 1.52 & 2.34 & S. distentus \\
\hline 8 & 29.20 & 2.41 & 1.05 & 2.30 & S. predistentus & 8 & 29.20 & 4.00 & 1.60 & 2.49 & S. distentus \\
\hline 8 & 29.20 & 3.01 & 1.24 & 2.42 & S. predistentus & 8 & 29.20 & 3.00 & 0.88 & 3.39 & S. distentus \\
\hline 8 & 29.20 & 2.98 & 1.16 & 2.56 & S. predistentus & 8 & 29.20 & 3.41 & 2.16 & 1.58 & S. distentus \\
\hline 8 & 29.20 & 4.29 & 1.72 & 2.50 & S. predistentus & 8 & 29.20 & 3.64 & 1.92 & 1.90 & S. distentus \\
\hline 8 & 29.20 & 3.96 & 1.31 & 3.03 & S. predistentus & 8 & 29.20 & 2.87 & 1.49 & 1.92 & S. distentus \\
\hline 8 & 29.20 & 2.52 & 0.85 & 2.96 & S. predistentus & 8 & 29.20 & 3.41 & 1.52 & 2.24 & S. distentus \\
\hline 8 & 29.20 & 3.05 & 1.29 & 2.35 & S. predistentus & 8 & 29.20 & 3.54 & 2.13 & 1.66 & S. ciperoensis? \\
\hline
\end{tabular}

Table A1. Continued.

Table A1. Continued. 
T. Blaj et al.

\begin{tabular}{|c|c|c|c|c|c|}
\hline $\begin{array}{l}\text { Sample } \\
\text { \# }\end{array}$ & $\begin{array}{l}\text { Age } \\
\text { (Ma) }\end{array}$ & $\begin{array}{l}\text { Width } \\
(\mu \mathrm{m})\end{array}$ & $\begin{array}{c}\text { Height } \\
(\mu \mathrm{m})\end{array}$ & $\begin{array}{l}\text { Ratio } \\
\text { W/H }\end{array}$ & Species ID \\
\hline 8 & 29.20 & 3.70 & 2.33 & 1.59 & S. ciperoensis? \\
\hline 8 & 29.20 & 3.68 & 2.13 & 1.73 & S. ciperoensis? \\
\hline 8 & 29.20 & 3.31 & 2.10 & 1.58 & S. ciperoensis? \\
\hline 9 & 29.51 & 3.57 & 1.23 & 2.91 & S. predistentus \\
\hline 9 & 29.51 & 2.45 & 0.95 & 2.59 & S. predistentus \\
\hline 9 & 29.51 & 3.06 & 0.92 & 3.34 & S. predistentus \\
\hline 9 & 29.51 & 3.22 & 0.97 & 3.34 & S. predistentus \\
\hline 9 & 29.51 & 3.24 & 1.24 & 2.61 & S. predistentus \\
\hline 9 & 29.51 & 3.13 & 1.03 & 3.03 & S. predistentus \\
\hline 9 & 29.51 & 2.49 & 0.80 & 3.10 & S. predistentus \\
\hline 9 & 29.51 & 3.11 & 1.28 & 2.44 & S. predistentus \\
\hline 9 & 29.51 & 2.95 & 1.05 & 2.81 & S. predistentus \\
\hline 9 & 29.51 & 3.84 & 1.21 & 3.18 & S. predistentus \\
\hline 9 & 29.51 & 3.62 & 1.37 & 2.63 & S. predistentus \\
\hline 9 & 29.51 & 2.41 & 0.74 & 3.27 & S. predistentus \\
\hline 9 & 29.51 & 2.68 & 1.11 & 2.41 & S. predistentus \\
\hline 9 & 29.51 & 2.59 & 0.85 & 3.04 & S. predistentus \\
\hline 9 & 29.51 & 3.53 & 1.24 & 2.84 & S. predistentus \\
\hline 9 & 29.51 & 3.99 & 1.62 & 2.46 & S. predistentus \\
\hline 9 & 29.51 & 3.89 & 1.47 & 2.64 & S. predistentus \\
\hline 9 & 29.51 & 3.17 & 0.90 & 3.53 & S. predistentus \\
\hline 9 & 29.51 & 3.09 & 1.21 & 2.55 & S. predistentus \\
\hline 9 & 29.51 & 3.57 & 1.46 & 2.45 & S. predistentus \\
\hline 9 & 29.51 & 3.13 & 1.13 & 2.77 & S. predistentus \\
\hline 9 & 29.51 & 2.90 & 1.36 & 2.13 & S. predistentus \\
\hline 9 & 29.51 & 3.24 & 1.42 & 2.28 & S. predistentus \\
\hline 9 & 29.51 & 2.81 & 1.10 & 2.57 & S. predistentus \\
\hline 9 & 29.51 & 2.73 & 1.29 & 2.11 & S. predistentus \\
\hline 9 & 29.51 & 3.19 & 1.29 & 2.47 & S. predistentus \\
\hline 9 & 29.51 & 2.85 & 1.26 & 2.26 & S. predistentus \\
\hline 9 & 29.51 & 3.84 & 1.52 & 2.53 & S. predistentus \\
\hline 9 & 29.51 & 3.86 & 1.36 & 2.84 & S. predistentus \\
\hline 9 & 29.51 & 3.35 & 1.31 & 2.56 & S. predistentus \\
\hline 9 & 29.51 & 2.68 & 1.36 & 1.98 & S. predistentus \\
\hline 9 & 29.51 & 3.42 & 1.23 & 2.79 & S. predistentus \\
\hline 9 & 29.51 & 3.80 & 1.28 & 2.97 & S. predistentus \\
\hline 9 & 29.51 & 3.27 & 1.15 & 2.86 & S. predistentus \\
\hline 9 & 29.51 & 2.75 & 0.70 & 3.91 & S. predistentus \\
\hline 9 & 29.51 & 3.32 & 1.05 & 3.17 & S. predistentus \\
\hline 9 & 29.51 & 2.83 & 0.74 & 3.84 & S. predistentus \\
\hline 9 & 29.51 & 3.27 & 1.06 & 3.08 & S. predistentus \\
\hline 9 & 29.51 & 2.77 & 0.74 & 3.76 & S. predistentus \\
\hline 9 & 29.51 & 3.40 & 1.24 & 2.74 & S. predistentus \\
\hline 9 & 29.51 & 3.31 & 1.08 & 3.06 & S. predistentus \\
\hline 9 & 29.51 & 2.49 & 0.93 & 2.67 & S. predistentus \\
\hline 9 & 29.51 & 3.53 & 1.33 & 2.67 & S. predistentus \\
\hline 9 & 29.51 & 2.70 & 1.15 & 2.36 & S. predistentus \\
\hline 9 & 29.51 & 3.01 & 1.16 & 2.59 & S. predistentus \\
\hline 9 & 29.51 & 3.96 & 1.54 & 2.57 & S. predistentus \\
\hline 9 & 29.51 & 3.04 & 1.03 & 2.95 & S. predistentus \\
\hline 9 & 29.51 & 3.50 & 1.37 & 2.55 & S. predistentus \\
\hline 9 & 29.51 & 3.08 & 1.42 & 2.16 & S. predistentus \\
\hline 9 & 29.51 & 3.27 & 1.16 & 2.82 & S. predistentus \\
\hline 9 & 29.51 & 2.62 & 1.10 & 2.39 & S. predistentus \\
\hline 9 & 29.51 & 3.09 & 1.11 & 2.78 & S. predistentus \\
\hline 9 & 29.51 & 3.09 & 1.19 & 2.59 & S. predistentus \\
\hline 9 & 29.51 & 2.65 & 1.03 & 2.57 & S. predistentus \\
\hline 9 & 29.51 & 3.24 & 1.60 & 2.02 & S. predistentus \\
\hline 9 & 29.51 & 3.66 & 1.21 & 3.03 & S. predistentus \\
\hline 9 & 29.51 & 2.80 & 0.97 & 2.90 & S. predistentus \\
\hline 9 & 29.51 & 3.94 & 1.26 & 3.13 & S. predistentus \\
\hline 9 & 29.51 & 2.73 & 1.08 & 2.53 & S. predistentus \\
\hline 9 & 29.51 & 3.13 & 1.16 & 2.69 & S. predistentus \\
\hline
\end{tabular}

\begin{tabular}{|c|c|c|c|c|c|}
\hline $\begin{array}{l}\text { Sample } \\
\#\end{array}$ & $\begin{array}{l}\text { Age } \\
(\mathrm{Ma})\end{array}$ & $\begin{array}{l}\text { Width } \\
(\mu \mathrm{m})\end{array}$ & $\begin{array}{l}\text { Height } \\
(\mu \mathrm{m})\end{array}$ & $\begin{array}{l}\text { Ratio } \\
\text { W/H }\end{array}$ & Species ID \\
\hline 9 & 29.51 & 4.14 & 1.52 & 2.72 & S. predistentus \\
\hline 9 & 29.51 & 4.24 & 1.65 & 2.56 & S. predistentus \\
\hline 9 & 29.51 & 3.73 & 1.13 & 3.30 & S. predistentus \\
\hline 9 & 29.51 & 2.90 & 1.11 & 2.60 & S. predistentus \\
\hline 9 & 29.51 & 3.29 & 1.44 & 2.28 & S. predistentus \\
\hline 9 & 29.51 & 3.94 & 1.24 & 3.17 & S. predistentus \\
\hline 9 & 29.51 & 3.16 & 1.01 & 3.11 & S. predistentus \\
\hline 9 & 29.51 & 3.08 & 0.98 & 3.13 & S. predistentus \\
\hline 9 & 29.51 & 3.57 & 1.37 & 2.60 & S. predistentus \\
\hline 9 & 29.51 & 2.91 & 1.06 & 2.74 & S. predistentus \\
\hline 9 & 29.51 & 3.14 & 1.24 & 2.53 & S. predistentus \\
\hline 9 & 29.51 & 2.86 & 1.05 & 2.73 & S. predistentus \\
\hline 9 & 29.51 & 3.45 & 1.46 & 2.37 & S. predistentus \\
\hline 9 & 29.51 & 3.17 & 1.36 & 2.34 & S. predistentus \\
\hline 9 & 29.51 & 3.16 & 1.52 & 2.08 & S. distentus \\
\hline 9 & 29.51 & 2.81 & 1.44 & 1.95 & S. distentus \\
\hline 9 & 29.51 & 3.14 & 1.39 & 2.26 & S. distentus \\
\hline 9 & 29.51 & 3.32 & 1.57 & 2.11 & S. distentus \\
\hline 9 & 29.51 & 3.14 & 0.97 & 3.25 & S. distentus \\
\hline 9 & 29.51 & 3.01 & 1.26 & 2.39 & S. distentus \\
\hline 9 & 29.51 & 2.47 & 1.41 & 1.76 & S. distentus \\
\hline 9 & 29.51 & 2.95 & 1.37 & 2.14 & S. distentus \\
\hline 9 & 29.51 & 3.37 & 1.64 & 2.06 & S. distentus \\
\hline 9 & 29.51 & 3.34 & 1.90 & 1.76 & S. distentus \\
\hline 9 & 29.51 & 3.53 & 1.90 & 1.86 & S. distentus \\
\hline 9 & 29.51 & 3.29 & 1.29 & 2.54 & S. distentus \\
\hline 9 & 29.51 & 3.01 & 1.26 & 2.39 & S. distentus \\
\hline 9 & 29.51 & 3.62 & 1.39 & 2.60 & S. distentus \\
\hline 9 & 29.51 & 3.40 & 1.60 & 2.12 & S. distentus \\
\hline 9 & 29.51 & 3.88 & 1.64 & 2.37 & S. distentus \\
\hline 9 & 29.51 & 2.52 & 0.85 & 2.96 & S. distentus \\
\hline 9 & 29.51 & 3.06 & 1.28 & 2.40 & S. distentus \\
\hline 9 & 29.51 & 3.44 & 1.52 & 2.26 & S. distentus \\
\hline 9 & 29.51 & 3.58 & 1.31 & 2.74 & S. distentus \\
\hline 9 & 29.51 & 2.54 & 1.18 & 2.15 & S. distentus \\
\hline 9 & 29.51 & 2.95 & 1.16 & 2.54 & S. distentus \\
\hline 9 & 29.51 & 3.24 & 1.41 & 2.30 & S. distentus \\
\hline 9 & 29.51 & 3.27 & 1.54 & 2.13 & S. distentus \\
\hline 9 & 29.51 & 3.21 & 1.34 & 2.39 & S. distentus \\
\hline 9 & 29.51 & 3.37 & 1.34 & 2.51 & S. distentus \\
\hline 10 & 29.86 & 2.91 & 0.97 & 3.02 & S. predistentus \\
\hline 10 & 29.86 & 3.05 & 1.13 & 2.70 & S. predistentus \\
\hline 10 & 29.86 & 2.98 & 1.05 & 2.84 & S. predistentus \\
\hline 10 & 29.86 & 3.09 & 1.13 & 2.74 & S. predistentus \\
\hline 10 & 29.86 & 3.41 & 1.11 & 3.06 & S. predistentus \\
\hline 10 & 29.86 & 3.78 & 1.13 & 3.35 & S. predistentus \\
\hline 10 & 29.86 & 3.21 & 0.77 & 4.17 & S. predistentus \\
\hline 10 & 29.86 & 2.96 & 1.06 & 2.78 & S. predistentus \\
\hline 10 & 29.86 & 2.62 & 0.85 & 3.08 & S. predistentus \\
\hline 10 & 29.86 & 3.16 & 1.13 & 2.80 & S. predistentus \\
\hline 10 & 29.86 & 3.34 & 1.33 & 2.52 & S. predistentus \\
\hline 10 & 29.86 & 3.06 & 0.87 & 3.53 & S. predistentus \\
\hline 10 & 29.86 & 2.41 & 0.88 & 2.72 & S. predistentus \\
\hline 10 & 29.86 & 3.47 & 1.28 & 2.72 & S. predistentus \\
\hline 10 & 29.86 & 2.72 & 0.95 & 2.86 & S. predistentus \\
\hline 10 & 29.86 & 3.09 & 0.98 & 3.15 & S. predistentus \\
\hline 10 & 29.86 & 2.77 & 0.97 & 2.86 & S. predistentus \\
\hline 10 & 29.86 & 3.37 & 0.98 & 3.43 & S. predistentus \\
\hline 10 & 29.86 & 3.67 & 1.11 & 3.29 & S. predistentus \\
\hline 10 & 29.86 & 2.41 & 0.69 & 3.50 & S. predistentus \\
\hline 10 & 29.86 & 3.31 & 0.87 & 3.81 & S. predistentus \\
\hline 10 & 29.86 & 3.00 & 0.82 & 3.66 & S. predistentus \\
\hline 10 & 29.86 & 3.24 & 1.05 & 3.09 & S. predistentus \\
\hline
\end{tabular}

Table A1. Continued.

Table A1. Continued. 


\begin{tabular}{|c|c|c|c|c|c|c|c|c|c|c|c|}
\hline $\begin{array}{l}\text { Sample } \\
\#\end{array}$ & $\begin{array}{l}\text { Age } \\
\text { (Ma) }\end{array}$ & $\begin{array}{l}\text { Width } \\
(\mu \mathrm{m})\end{array}$ & $\begin{array}{c}\text { Height } \\
(\mu \mathrm{m})\end{array}$ & $\begin{array}{c}\text { Ratio } \\
\text { W/H }\end{array}$ & Species ID & $\begin{array}{l}\text { Sample } \\
\#\end{array}$ & $\begin{array}{l}\text { Age } \\
(\mathrm{Ma})\end{array}$ & $\begin{array}{l}\text { Width } \\
(\mu \mathrm{m})\end{array}$ & $\begin{array}{c}\text { Height } \\
(\mu \mathrm{m})\end{array}$ & $\begin{array}{c}\text { Ratio } \\
\text { W/H }\end{array}$ & Species ID \\
\hline 10 & 29.86 & 2.96 & 0.90 & 3.29 & S. predistentus & 10 & 29.86 & 3.09 & 1.78 & 1.73 & S. distentus \\
\hline 10 & 29.86 & 2.78 & 0.77 & 3.62 & S. predistentus & 10 & 29.86 & 3.50 & 1.28 & 2.74 & S. distentus \\
\hline 10 & 29.86 & 2.73 & 0.67 & 4.07 & S. predistentus & 10 & 29.86 & 3.21 & 1.51 & 2.13 & S. distentus \\
\hline 10 & 29.86 & 2.72 & 0.82 & 3.32 & S. predistentus & 10 & 29.86 & 3.18 & 1.24 & 2.55 & S. distentus \\
\hline 10 & 29.86 & 3.32 & 1.00 & 3.33 & S. predistentus & 10 & 29.86 & 3.65 & 1.29 & 2.82 & S. distentus \\
\hline 10 & 29.86 & 4.00 & 1.44 & 2.77 & S. predistentus & 10 & 29.86 & 3.29 & 1.18 & 2.79 & S. distentus \\
\hline 10 & 29.86 & 2.78 & 0.75 & 3.70 & S. predistentus & 10 & 29.86 & 3.31 & 1.03 & 3.21 & S. distentus \\
\hline 10 & 29.86 & 3.00 & 1.11 & 2.69 & S. predistentus & 10 & 29.86 & 3.23 & 1.39 & 2.32 & S. distentus \\
\hline 10 & 29.86 & 3.08 & 1.26 & 2.44 & S. predistentus & 10 & 29.86 & 2.51 & 1.11 & 2.25 & S. distentus \\
\hline 10 & 29.86 & 3.13 & 1.16 & 2.69 & S. predistentus & 10 & 29.86 & 3.54 & 1.06 & 3.32 & S. distentus \\
\hline 10 & 29.86 & 3.42 & 0.84 & 4.10 & S. predistentus & 10 & 29.86 & 2.98 & 1.36 & 2.19 & S. distentus \\
\hline 10 & 29.86 & 2.85 & 0.90 & 3.16 & S. predistentus & 11 & 31.6 & 1.85 & 0.69 & 2.67 & transitional \\
\hline 10 & 29.86 & 3.46 & 1.16 & 2.97 & S. predistentus & 11 & 31.6 & 1.91 & 0.90 & 2.13 & transitional \\
\hline 10 & 29.86 & 3.52 & 0.85 & 4.13 & S. predistentus & 11 & 31.6 & 1.89 & 0.80 & 2.35 & transitional \\
\hline 10 & 29.86 & 3.34 & 0.98 & 3.40 & S. predistentus & 11 & 31.6 & 2.22 & 0.71 & 3.12 & transitional \\
\hline 10 & 29.86 & 3.68 & 1.02 & 3.63 & S. predistentus & 11 & 31.6 & 2.74 & 1.27 & 2.17 & transitional \\
\hline 10 & 29.86 & 3.18 & 1.20 & 2.66 & S. predistentus & 11 & 31.6 & 1.78 & 0.67 & 2.67 & transitional \\
\hline 10 & 29.86 & 3.62 & 1.24 & 2.91 & S. predistentus & 11 & 31.6 & 1.70 & 0.70 & 2.41 & transitional \\
\hline 10 & 29.86 & 2.88 & 1.05 & 2.75 & S. predistentus & 11 & 31.6 & 2.08 & 0.96 & 2.18 & transitional \\
\hline 10 & 29.86 & 2.77 & 0.70 & 3.93 & S. predistentus & 11 & 31.6 & 1.99 & 0.90 & 2.20 & transitional \\
\hline 10 & 29.86 & 3.34 & 1.20 & 2.79 & S. predistentus & 11 & 31.6 & 2.01 & 0.84 & 2.38 & transitional \\
\hline 10 & 29.86 & 2.98 & 0.93 & 3.19 & S. predistentus & 11 & 31.6 & 2.23 & 1.16 & 1.93 & transitional \\
\hline 10 & 29.86 & 2.72 & 0.84 & 3.25 & S. predistentus & 11 & 31.6 & 2.64 & 1.06 & 2.50 & transitional \\
\hline 10 & 29.86 & 2.64 & 0.87 & 3.04 & S. predistentus & 11 & 31.6 & 2.43 & 1.08 & 2.24 & transitional \\
\hline 10 & 29.86 & 3.72 & 1.03 & 3.60 & S. predistentus & 11 & 31.6 & 2.20 & 0.67 & 3.30 & transitional \\
\hline 10 & 29.86 & 2.91 & 0.87 & 3.36 & S. predistentus & 11 & 31.6 & 2.03 & 0.99 & 2.06 & transitional \\
\hline 10 & 29.86 & 3.50 & 1.29 & 2.71 & S. predistentus & 11 & 31.6 & 1.81 & 0.59 & 3.08 & S. predistentus \\
\hline 10 & 29.86 & 2.95 & 1.00 & 2.95 & S. predistentus & 11 & 31.6 & 1.86 & 0.60 & 3.12 & S. predistentus \\
\hline 10 & 29.86 & 2.88 & 1.23 & 2.35 & S. predistentus & 11 & 31.6 & 1.86 & 0.59 & 3.12 & S. predistentus \\
\hline 10 & 29.86 & 2.28 & 0.97 & 2.36 & S. predistentus & 11 & 31.6 & 2.14 & 0.90 & 2.39 & S. predistentus \\
\hline 10 & 29.86 & 3.23 & 1.20 & 2.70 & S. predistentus & 11 & 31.6 & 2.28 & 0.64 & 3.56 & S. predistentus \\
\hline 10 & 29.86 & 3.57 & 1.21 & 2.95 & S. predistentus & 11 & 31.6 & 2.43 & 0.92 & 2.65 & S. predistentus \\
\hline 10 & 29.86 & 3.60 & 1.39 & 2.59 & S. predistentus & 11 & 31.6 & 2.20 & 0.48 & 4.53 & S. predistentus \\
\hline 10 & 29.86 & 3.49 & 1.33 & 2.63 & S. predistentus & 11 & 31.6 & 1.76 & 0.29 & 6.03 & S. predistentus \\
\hline 10 & 29.86 & 2.51 & 0.82 & 3.06 & S. predistentus & 11 & 31.6 & 2.15 & 0.55 & 3.88 & S. predistentus \\
\hline 10 & 29.86 & 3.23 & 1.34 & 2.40 & S. predistentus & 11 & 31.6 & 1.37 & 0.51 & 2.68 & S. predistentus \\
\hline 10 & 29.86 & 2.91 & 1.41 & 2.07 & S. predistentus & 11 & 31.6 & 2.02 & 0.52 & 3.88 & S. predistentus \\
\hline 10 & 29.86 & 2.75 & 0.92 & 3.00 & S. predistentus & 11 & 31.6 & 2.34 & 0.39 & 6.00 & S. predistentus \\
\hline 10 & 29.86 & 3.03 & 1.24 & 2.43 & S. predistentus & 11 & 31.6 & 1.96 & 0.58 & 3.40 & S. predistentus \\
\hline 10 & 29.86 & 3.60 & 1.15 & 3.14 & S. predistentus & 11 & 31.6 & 2.61 & 1.14 & 2.30 & S. predistentus \\
\hline 10 & 29.86 & 2.88 & 1.05 & 2.75 & S. predistentus & 11 & 31.6 & 2.50 & 0.68 & 3.70 & S. predistentus \\
\hline 10 & 29.86 & 2.54 & 1.08 & 2.35 & S. distentus & 11 & 31.6 & 2.03 & 0.68 & 2.98 & S. predistentus \\
\hline 10 & 29.86 & 2.55 & 1.08 & 2.36 & S. distentus & 11 & 31.6 & 2.13 & 0.51 & 4.16 & S. predistentus \\
\hline 10 & 29.86 & 2.78 & 1.21 & 2.30 & S. distentus & 11 & 31.6 & 2.34 & 0.46 & 5.13 & S. predistentus \\
\hline 10 & 29.86 & 2.72 & 1.23 & 2.21 & S. distentus & 11 & 31.6 & 1.73 & 0.44 & 3.92 & S. predistentus \\
\hline 10 & 29.86 & 3.14 & 1.47 & 2.13 & S. distentus & 11 & 31.6 & 2.17 & 0.71 & 3.07 & S. predistentus \\
\hline 10 & 29.86 & 2.98 & 1.16 & 2.56 & S. distentus & 11 & 31.6 & 2.36 & 0.80 & 2.95 & S. predistentus \\
\hline
\end{tabular}

Table A1. Continued.

Table A1. Continued. 
T. Blaj et al.

\begin{tabular}{|c|c|c|c|c|c|}
\hline $\begin{array}{l}\text { Sample } \\
\text { \# }\end{array}$ & $\begin{array}{l}\text { Age } \\
\text { (Ma) }\end{array}$ & $\begin{array}{c}\text { Width } \\
(\mu \mathrm{m})\end{array}$ & $\begin{array}{c}\text { Height } \\
(\mu \mathrm{m})\end{array}$ & $\begin{array}{l}\text { Ratio } \\
\text { W/H }\end{array}$ & Species ID \\
\hline 11 & 31.6 & 2.05 & 0.58 & 3.55 & S. predistentus \\
\hline 11 & 31.6 & 2.40 & 0.47 & 5.13 & S. predistentus \\
\hline 11 & 31.6 & 2.46 & 0.47 & 5.25 & S. predistentus \\
\hline 11 & 31.6 & 1.94 & 0.43 & 4.50 & S. predistentus \\
\hline 11 & 31.6 & 2.06 & 0.34 & 6.02 & S. predistentus \\
\hline 11 & 31.6 & 2.13 & 0.73 & 2.93 & S. predistentus \\
\hline 11 & 31.6 & 2.06 & 0.50 & 4.13 & S. predistentus \\
\hline 11 & 31.6 & 1.89 & 0.35 & 5.34 & S. predistentus \\
\hline 11 & 31.6 & 1.86 & 0.63 & 2.96 & S. predistentus \\
\hline 11 & 31.6 & 1.96 & 0.64 & 3.08 & S. predistentus \\
\hline 11 & 31.6 & 1.56 & 0.59 & 2.64 & S. predistentus \\
\hline 11 & 31.6 & 2.14 & 0.45 & 4.79 & S. predistentus \\
\hline 11 & 31.6 & 2.31 & 0.98 & 2.35 & S. predistentus \\
\hline 11 & 31.6 & 3.20 & 0.77 & 4.17 & S. predistentus \\
\hline 11 & 31.6 & 2.50 & 0.87 & 2.87 & S. predistentus \\
\hline 11 & 31.6 & 2.43 & 0.86 & 2.82 & S. predistentus \\
\hline 11 & 31.6 & 1.72 & 0.58 & 2.95 & S. predistentus \\
\hline 11 & 31.6 & 1.81 & 0.79 & 2.30 & S. predistentus \\
\hline 11 & 31.6 & 1.99 & 0.74 & 2.70 & S. predistentus \\
\hline 11 & 31.6 & 1.80 & 0.78 & 2.31 & S. predistentus \\
\hline 11 & 31.6 & 1.71 & 0.63 & 2.73 & S. predistentus \\
\hline 11 & 31.6 & 2.37 & 1.03 & 2.31 & S. predistentus \\
\hline 11 & 31.6 & 1.70 & 0.60 & 2.85 & S. predistentus \\
\hline 11 & 31.6 & 1.74 & 0.40 & 4.38 & S. predistentus \\
\hline 11 & 31.6 & 2.76 & 0.65 & 4.26 & S. predistentus \\
\hline 11 & 31.6 & 1.86 & 0.57 & 3.24 & S. predistentus \\
\hline 11 & 31.6 & 2.27 & 0.64 & 3.54 & S. predistentus \\
\hline 11 & 31.6 & 1.97 & 0.51 & 3.83 & S. predistentus \\
\hline 11 & 31.6 & 2.58 & 0.95 & 2.72 & S. predistentus \\
\hline 11 & 31.6 & 1.86 & 0.62 & 3.01 & S. predistentus \\
\hline 11 & 31.6 & 2.64 & 0.91 & 2.91 & S. predistentus \\
\hline 11 & 31.6 & 2.45 & 0.51 & 4.78 & S. predistentus \\
\hline 11 & 31.6 & 2.41 & 0.36 & 6.77 & S. predistentus \\
\hline 11 & 31.6 & 1.81 & 0.58 & 3.12 & S. predistentus \\
\hline 11 & 31.6 & 2.25 & 0.51 & 4.44 & S. predistentus \\
\hline 11 & 31.6 & 2.23 & 0.66 & 3.39 & S. predistentus \\
\hline 11 & 31.6 & 1.98 & 0.46 & 4.30 & S. predistentus \\
\hline 11 & 31.6 & 2.35 & 0.43 & 5.40 & S. predistentus \\
\hline 11 & 31.6 & 2.12 & 0.92 & 2.31 & S. predistentus \\
\hline 11 & 31.6 & 2.17 & 0.49 & 4.45 & S. predistentus \\
\hline 11 & 31.6 & 2.04 & 0.67 & 3.06 & S. predistentus \\
\hline 11 & 31.6 & 2.00 & 0.61 & 3.29 & S. predistentus \\
\hline 11 & 31.6 & 2.55 & 0.42 & 6.11 & S. predistentus \\
\hline 11 & 31.6 & 2.56 & 0.94 & 2.72 & S. predistentus \\
\hline 11 & 31.6 & 1.90 & 0.70 & 2.73 & S. predistentus \\
\hline 11 & 31.6 & 1.89 & 0.75 & 2.54 & S. predistentus \\
\hline 11 & 31.6 & 1.84 & 0.48 & 3.82 & S. predistentus \\
\hline 11 & 31.6 & 3.09 & 1.07 & 2.90 & S. predistentus \\
\hline 11 & 31.6 & 2.04 & 0.74 & 2.77 & S. predistentus \\
\hline 11 & 31.6 & 1.84 & 0.48 & 3.86 & S. predistentus \\
\hline 11 & 31.6 & 2.06 & 0.74 & 2.78 & S. predistentus \\
\hline 11 & 31.6 & 1.68 & 0.76 & 2.19 & S. predistentus \\
\hline 11 & 31.6 & 1.91 & 0.52 & 3.65 & S. predistentus \\
\hline 11 & 31.6 & 1.87 & 0.47 & 3.99 & S. predistentus \\
\hline 11 & 31.6 & 1.82 & 0.55 & 3.32 & S. predistentus \\
\hline 11 & 31.6 & 2.23 & 0.62 & 3.60 & S. predistentus \\
\hline 11 & 31.6 & 1.94 & 0.55 & 3.52 & S. predistentus \\
\hline 11 & 31.6 & 1.79 & 0.40 & 4.47 & S. predistentus \\
\hline 11 & 31.6 & 2.22 & 0.63 & 3.55 & S. predistentus \\
\hline 12 & 33.02 & 2.12 & 0.72 & 2.94 & transitional \\
\hline 12 & 33.02 & 3.03 & 0.96 & 3.16 & transitional \\
\hline 12 & 33.02 & 2.65 & 0.95 & 2.78 & transitional \\
\hline 12 & 33.02 & 2.77 & 0.95 & 2.93 & transitional \\
\hline
\end{tabular}

\begin{tabular}{|c|c|c|c|c|c|}
\hline $\begin{array}{l}\text { Sample } \\
\text { \# }\end{array}$ & $\begin{array}{l}\text { Age } \\
(\mathrm{Ma})\end{array}$ & $\begin{array}{l}\text { Width } \\
(\mu \mathrm{m})\end{array}$ & $\begin{array}{c}\text { Height } \\
(\mu \mathrm{m})\end{array}$ & $\begin{array}{l}\text { Ratio } \\
\text { W/H }\end{array}$ & Species ID \\
\hline 12 & 33.02 & 2.27 & 0.81 & 2.79 & transitional \\
\hline 12 & 33.02 & 2.00 & 0.64 & 3.14 & transitional \\
\hline 12 & 33.02 & 2.43 & 0.98 & 2.48 & transitional \\
\hline 12 & 33.02 & 2.69 & 0.98 & 2.74 & transitional \\
\hline 12 & 33.02 & 2.55 & 0.93 & 2.73 & transitional \\
\hline 12 & 33.02 & 2.23 & 0.62 & 3.61 & transitional \\
\hline 12 & 33.02 & 2.65 & 0.75 & 3.55 & transitional \\
\hline 12 & 33.02 & 3.36 & 1.02 & 3.29 & transitional \\
\hline 12 & 33.02 & 2.26 & 0.75 & 3.01 & transitional \\
\hline 12 & 33.02 & 2.79 & 0.75 & 3.72 & transitional \\
\hline 12 & 33.02 & 3.07 & 1.32 & 2.33 & transitional \\
\hline 12 & 33.02 & 2.32 & 0.70 & 3.29 & transitional \\
\hline 12 & 33.02 & 2.31 & 0.70 & 3.30 & transitional \\
\hline 12 & 33.02 & 1.93 & 0.62 & 3.09 & transitional \\
\hline 12 & 33.02 & 2.56 & 0.52 & 4.90 & S. predistentus \\
\hline 12 & 33.02 & 2.27 & 0.55 & 4.10 & S. predistentus \\
\hline 12 & 33.02 & 2.47 & 0.54 & 4.58 & S. predistentus \\
\hline 12 & 33.02 & 2.72 & 0.73 & 3.75 & S. predistentus \\
\hline 12 & 33.02 & 2.94 & 0.98 & 3.00 & S. predistentus \\
\hline 12 & 33.02 & 2.77 & 0.75 & 3.71 & S. predistentus \\
\hline 12 & 33.02 & 2.62 & 0.78 & 3.36 & S. predistentus \\
\hline 12 & 33.02 & 1.92 & 0.55 & 3.48 & S. predistentus \\
\hline 12 & 33.02 & 2.53 & 0.58 & 4.34 & S. predistentus \\
\hline 12 & 33.02 & 2.33 & 0.74 & 3.16 & S. predistentus \\
\hline 12 & 33.02 & 2.21 & 0.56 & 3.94 & S. predistentus \\
\hline 12 & 33.02 & 3.63 & 0.91 & 4.00 & S. predistentus \\
\hline 12 & 33.02 & 2.16 & 0.60 & 3.59 & S. predistentus \\
\hline 12 & 33.02 & 2.56 & 0.77 & 3.31 & S. predistentus \\
\hline 12 & 33.02 & 3.06 & 0.79 & 3.90 & S. predistentus \\
\hline 12 & 33.02 & 2.29 & 0.57 & 4.05 & S. predistentus \\
\hline 12 & 33.02 & 1.95 & 0.63 & 3.09 & S. predistentus \\
\hline 12 & 33.02 & 2.20 & 0.69 & 3.19 & S. predistentus \\
\hline 12 & 33.02 & 2.69 & 0.81 & 3.34 & S. predistentus \\
\hline 12 & 33.02 & 3.30 & 0.98 & 3.35 & S. predistentus \\
\hline 12 & 33.02 & 3.09 & 0.55 & 5.58 & S. predistentus \\
\hline 12 & 33.02 & 2.36 & 0.73 & 3.26 & S. predistentus \\
\hline 12 & 33.02 & 2.33 & 0.70 & 3.32 & S. predistentus \\
\hline 12 & 33.02 & 3.12 & 0.61 & 5.08 & S. predistentus \\
\hline 12 & 33.02 & 2.46 & 0.72 & 3.40 & S. predistentus \\
\hline 12 & 33.02 & 2.68 & 0.64 & 4.15 & S. predistentus \\
\hline 12 & 33.02 & 2.39 & 0.55 & 4.38 & S. predistentus \\
\hline 12 & 33.02 & 2.69 & 0.66 & 4.07 & S. predistentus \\
\hline 12 & 33.02 & 2.48 & 0.55 & 4.51 & S. predistentus \\
\hline 12 & 33.02 & 2.35 & 0.97 & 2.41 & S. predistentus \\
\hline 12 & 33.02 & 2.59 & 0.44 & 5.84 & S. predistentus \\
\hline 12 & 33.02 & 3.13 & 0.83 & 3.78 & S. predistentus \\
\hline 12 & 33.02 & 2.28 & 0.55 & 4.15 & S. predistentus \\
\hline 12 & 33.02 & 2.76 & 0.64 & 4.33 & S. predistentus \\
\hline 12 & 33.02 & 2.80 & 0.72 & 3.86 & S. predistentus \\
\hline 12 & 33.02 & 2.70 & 0.44 & 6.12 & S. predistentus \\
\hline 12 & 33.02 & 1.99 & 0.48 & 4.12 & S. predistentus \\
\hline 12 & 33.02 & 2.63 & 0.60 & 4.39 & S. predistentus \\
\hline 12 & 33.02 & 2.62 & 0.54 & 4.87 & S. predistentus \\
\hline 12 & 33.02 & 2.06 & 0.39 & 5.27 & S. predistentus \\
\hline 12 & 33.02 & 2.06 & 0.39 & 5.27 & S. predistentus \\
\hline 12 & 33.02 & 3.07 & 0.83 & 3.70 & S. predistentus \\
\hline 12 & 33.02 & 1.99 & 0.50 & 3.97 & S. predistentus \\
\hline 12 & 33.02 & 2.59 & 0.58 & 4.48 & S. predistentus \\
\hline 12 & 33.02 & 2.30 & 0.50 & 4.57 & S. predistentus \\
\hline 12 & 33.02 & 2.50 & 0.76 & 3.27 & S. predistentus \\
\hline 12 & 33.02 & 2.96 & 0.96 & 3.10 & S. predistentus \\
\hline 12 & 33.02 & 3.80 & 0.99 & 3.83 & S. predistentus \\
\hline 12 & 33.02 & 2.36 & 0.57 & 4.13 & S. predistentus \\
\hline
\end{tabular}

Table A1. Continued.

Table A1. Continued. 


\begin{tabular}{lccccc}
\hline Sample & Age & Width & $\begin{array}{c}\text { Height } \\
(\mu \mathrm{m})\end{array}$ & $\begin{array}{c}\text { Ratio } \\
\text { W/H }\end{array}$ & Species ID \\
\hline 12 & $(\mathrm{Ma})$ & $(\mu \mathrm{m})$ & & \\
12 & 33.02 & 3.89 & 1.15 & 3.39 & S. predistentus \\
12 & 33.02 & 2.27 & 0.49 & 4.67 & S. predistentus \\
12 & 33.02 & 2.48 & 0.68 & 3.64 & S. predistentus \\
12 & 33.02 & 2.33 & 0.45 & 5.22 & S. predistentus \\
12 & 33.02 & 3.01 & 0.53 & 5.68 & S. predistentus \\
12 & 33.02 & 3.09 & 0.70 & 4.39 & S. predistentus \\
12 & 33.02 & 2.12 & 0.61 & 3.50 & S. predistentus \\
12 & 33.02 & 2.72 & 0.50 & 5.40 & S. predistentus \\
12 & 33.02 & 2.15 & 0.65 & 3.32 & S. predistentus \\
12 & 33.02 & 2.66 & 0.45 & 5.94 & S. predistentus \\
12 & 33.02 & 2.36 & 0.64 & 3.65 & S. predistentus \\
12 & 33.02 & 2.33 & 0.50 & 4.66 & S. predistentus \\
12 & 33.02 & 2.15 & 0.41 & 5.26 & S. predistentus \\
12 & 33.02 & 2.87 & 0.46 & 6.29 & S. predistentus \\
12 & 33.02 & 2.21 & 0.60 & 3.67 & S. predistentus \\
12 & 33.02 & 2.70 & 0.66 & 4.11 & S. predistentus \\
12 & 33.02 & 2.73 & 0.88 & 3.12 & S. predistentus \\
12 & 33.02 & 2.24 & 0.61 & 3.67 & S. predistentus \\
12 & 33.02 & 2.20 & 0.47 & 4.73 & S. predistentus \\
12 & 33.02 & 3.41 & 0.99 & 3.43 & S. predistentus \\
12 & 33.02 & 2.57 & 0.65 & 3.95 & S. predistentus \\
12 & 33.02 & 2.12 & 0.42 & 5.02 & S. predistentus \\
12 & 33.02 & 2.33 & 0.52 & 4.48 & S. predistentus \\
12 & 33.02 & 2.80 & 0.75 & 3.75 & S. predistentus \\
12 & 33.02 & 3.39 & 0.82 & 4.12 & S. predistentus \\
12 & 33.02 & 2.76 & 0.65 & 4.26 & S. predistentus \\
12 & 33.02 & 3.12 & 0.91 & 3.41 & S. predistentus \\
12 & 33.02 & 3.09 & 0.96 & 3.22 & S. predistentus \\
12 & 33.02 & 2.60 & 0.63 & 4.14 & S. predistentus \\
12 & 33.02 & 2.67 & 0.59 & 4.54 & S. predistentus \\
12 & 33.02 & 2.64 & 0.63 & 4.20 & S. predistentus \\
12 & 33.02 & 2.47 & 0.66 & 3.77 & S. predistentus \\
12 & 33.02 & 2.84 & 0.90 & 3.15 & S. predistentus \\
12 & 33.02 & 2.53 & 0.70 & 3.64 & S. predistentus \\
12 & 33.02 & 3.14 & 0.82 & 3.83 & S. predistentus \\
12 & 33.02 & 2.22 & 0.59 & 3.76 & S. predistentus \\
12 & 33.02 & 3.93 & 0.61 & 3.16 & S. predistentus \\
12 & 33.02 & 3.19 & 0.77 & 4.45 & S. predistentus \\
12 & 33.02 & 2.31 & 0.61 & 5.27 & S. predistentus \\
\hline & & & & &
\end{tabular}

Table A1. Continued.

\section{REFERENCES}

Blaj, T., Backman, J. \& Raffi, I. 2009. Late Eocene to Oligocene preservation history and biochronology of calcareous nannofossils from paleo-equatorial Pacific Ocean sediments. Rivista Italiana di Paleontologia e Stratigrafia, 115(1): 67-85.

Bown, P.R., Lees, J.A. \& Young, J.R. 2004. Calcareous nannoplankton evolution and diversity through time. In: Thierstein, H.R. \& Young, J.R. (Eds), Coccolithophores: from molecular processes to global impact. Springer Verlag, Berlin, 481-508.

Bramlette, M.N. \& Wilcoxon, J.A. 1967. Middle Tertiary calcareous nannoplankton of the Cipero section, Trinidad, W.I. Tulane Studies in Geology and Paleontology, 5: 93-131.

Bukry, D. 1975. Coccolith and silicoflagellate stratigraphy, northwestern Pacific Ocean, Deep Sea Drilling Project Leg 32. In: Larsen, R.L., Moberly, R. et al. (Eds), Initial Reports of the Deep Sea Drilling Project, 32. US Government Printing Office, Washington, 677-701.
Bukry, D. 1978. Biostratigraphy of Cenozoic marine sediment by calcareous nannofossils. Micropaleontology, 24(1): 44-60.

Haq, B.U. 1971. Paleogene calcareous nannoflora, part III: Oligocene of Syria. Stockholm Contributions in Geology, 25: 99-127.

Haq, B.U. \& Lohmann, G.P. 1976. Early Cenozoic calcareous nannoplankton biogeography of the Atlantic Ocean. Marine Micropaleontology, 1: 119-194.

Henderiks, J. \& Pagani, M. 2008. Coccolithophore cell size and the Paleogene decline in atmospheric $\mathrm{CO} 2$. Earth and Planetary Science Letters, 269: 575-583.

Huang, T.-C. 1977. Calcareous nannoplankton stratigraphy of the Upper Wulai Group (Oligocene) in Northern Taiwan. Petroleum Geology of Taiwan, 14: 147-179.

Knappertsbusch, M. 2000. Morphologic evolution of the coccolithophorid Calcidiscus leptoporus from the Early Miocene to Recent. Journal of Paleontology, 74: 712-730.

Lanci, L., Parés, J.M., Channell, J.E.T. \& Kent, D.V. 2005. Oligocene magnetostratigraphy from equatorial Pacific sediments (ODP Sites 1218 and 1219, Leg 199). Earth and Planetary Science Letters, 237: 617-634.

Lyle, M., Wilson, P.A., Janecek, T.R. et al. 2002. Proceedings of the Ocean Drilling Project, Initial Reports, 199. College Station, TX (Ocean Drilling Program), DOI: 10.2973/odp.proc.ir.199.2002.

Martini, E. 1971. Standard Tertiary and Quaternary calcareous nannoplankton zonation. In: Farinacci, A. (Ed.), Proceedings of the 2nd International Conference on Planktonic Microfossils Roma, 2. Editioni Tecnoscienza, Rome, 739-785.

Moran, M.J. \& Watkins, D.K. 1988. Oligocene calcareous nannofossil biostratigraphy from Leg 101, Site 628, Little Bahama Bank Slope. In: Austin, J.A. Jr., Schlager, W. et al. (Eds), Proceedings of the ODP, Scientific Results, 101. College Station, TX (Ocean Drilling Program), 87-103.

Okada, H. 1990. Quaternary and Paleogene calcareous nannofossils, Leg 115. In: Duncan, R.A., Backman, J., Peterson, L.C. et al. (Eds), Proceedings of the ODP, Scientific Results, 115. College Station, TX (Ocean Drilling Program), 129-174, DOI: 10.2973/odp.proc.sr. 115.150.1990.

Okada, H. \& Bukry, D. 1980. Supplementary modification and introduction of code numbers to the low-latitude coccolith biostratigraphic zonation. Marine Micropaleontology, 5: 321-325.

Olafsson, G. \& Villa, G. 1992. Reliability of sphenoliths as zonal markers in Oligocene sediments from the Atlantic and Indian Oceans. Memorie di Scienze Geologiche, 43: 261-275.

Pälike, H., Norris, R.D., Herrle, J.O. et al. 2006. The heartbeat of the Oligocene climate system. Science, 314: 1894-1898.

Perch-Nielsen, K. 1985. Cenozoic calcareous nannofossils. In: Bolli, H.M., Saunders, J.B. \& Perch-Nielsen, K. (Eds), Plankton Stratigraphy. Cambridge University Press, Cambridge, 427-554.

Roth, P.H., Franz, H.E. \& Wise, S.W. Jr. 1970. Morphological study of the selected members of the genus Sphenolithus Delfandre (Incertae sedis, Tertiary). In: Forinacci, A. (Ed.), Proceedings of the II planktonic conference Roma 1970, 2. Editioni Tecnoscienza, Rome, 1099 1119.

Wilson, P.A., Lyle, M. \& Firth, J.V. (Eds). 2006. Proceedings of the ODP, Scientific Results, 199. College Station, TX (Ocean Drilling Program), DOI: 10.2973/odp.proc.sr.199.2006.

Young, J.R. 1990. Size variation of Neogene Reticulofenestra coccoliths from Indian Ocean DSDP Cores. Journal of Micropaleontology, 9: $71-86$.

Young, J.R. 1998. Neogene. In: Bown, P.R. (Ed.) Calcareous Nannofossil Biostratigraphy, 225-266. British Micropalaeontological Society Publication, Chapman \& Hall, Kluwer Academic Publishers, Amsterdam. 